\title{
LITERATURE REVIEW \\ Gray mold caused by Botrytis cinerea limits grape production in Chile
}

\author{
Bernardo A. Latorre, Karina Elfar, and Enrique E. Ferrada \\ Facultad de Agronomía e Ingeniería Forestal, Pontificia Universidad Católica de Chile, Santiago, Chile.
}

\begin{abstract}
B.A. Latorre, K. Elfar, and E.E. Ferrada. 2015. Gray mold caused by Botrytis cinerea limits grape production in Chile. Cien. Inv. Agr. 42(3): 305-330. Gray mold (GM) caused by Botrytis cinerea is a major disease of grapes (Vitis vinifera) that substantially reduces the yield and quality of grape production in temperate and humid regions of the world. $B$. cinerea is a necrotrophic fungus that attacks the non-lignified aerial organs of grapes; in particular, berries are highly susceptible during ripening. The polycyclic nature and exponential progress exhibited by GM at the beginning of the its epidemic, as well as the abundant inoculum production, the high dissemination efficiency, the wide host range and the high genetic variability of $B$. cinerea, explain the difficulties encountered in attempting to control GM. At present, integrated disease management, including cultural and chemical control, is the main control strategy. These control measures can be used to reduce the initial inoculum or to lower the disease infection rate. However, control measures that reduce the infection rate are the most effective means of controlling GM. Important progress toward understanding the complexity of the biology and epidemiology of this pathogen has occurred in recent decades. This has allowed the improvement and development of more effective and sustainable control strategies against $B$. cinerea. This review article provides a recent update regarding grape GM, with special emphasis on Chilean production conditions.
\end{abstract}

Key words: Botryotinia fuckeliana, bunch rot, epidemiology, fungicides, necrotroph, Vitis vinifera.

\section{Introduction}

Gray mold (GM) caused by Botrytis cinerea Pers. is the primary deteriorative factor affecting grapes (Vitis vinifera L.) in Chile and other grape-producing countries worldwide. GM reduces the yield and quality of wine and table grapes in geographical locations characterized by humid

Received April 16, 2015. Accepted September 14, 2015. Corresponding author: blatorre@uc.cl and temperate weather conditions during the spring and summer months.

Grape GM affects the aerial organs, i.e., the berries, which are highly susceptible from veraison (color change, berries with $>7 \%$ total soluble solids) to harvest. Grape GM is the most important cause of postharvest decay of table grapes during storage, transit to markets and commercialization. GM has limited table grape production in Chile, which is currently confined to relatively dry and temperate geographical 
locations extending from the Atacama (27 $22^{\prime}$ S) to the Maule (34⒐' S) regions, along a northsouth axis of approximately $1,000 \mathrm{~km}$.

Notable textbooks (Coley-Smith et al., 1980; Elad et al., 2004) and review articles (Jacometti et al., 2010; Mundy, 2008; Romanazzi et al., 2012; Steel et al., 2013; van Kan et al., 2014; Williamson et al., 2007) have been published on the biology, epidemiology and control of the disease caused by B. cinerea. In this article, we reviewed numerous studies and discuss the factors that affect grape GM, as well as control strategies with special reference to the Chilean situation. This review further expands upon previously discussed information (Latorre, 2007).

\section{Symptoms}

Symptoms of GM are observed on berries, leaves, shoots, buds and canes, of which berries are the most affected grape organ.

Berry symptoms often appear prior to harvest or during cold storage, transit or commercialization (Figure 1). Berry symptoms commonly appear as reddish-brown discoloration that starts at the pedicel end and progresses toward the stylar end (Holz et al., 2003). Small (approximately $0.5 \mathrm{~mm}$ in diameter), round, reddish-brown necrotic spots often appear on the berry cheek after rainfall near harvest time, and reddish-brown decay at the stylar end has been observed in Chilean vineyards (Zoffoli et al., 2009). As the berry infection progresses, a loose skin ('slip-skin'), berry split and soft and watery decay are observed. Infected berries usually leak, which favors the colonization and sporulation of $B$. cinerea on the berry surface and promotes the dissemination of $B$. cinerea to neighboring berries, forming a nest of rotted berries (Figure 1B). Finally, the infected berries dehydrate and shrivel, remaining as berry mummies attached to the clusters or on the ground litter.

Leaf symptoms appear early in the growing season and are characterized by small brown necrotic spots around the veins and brown " $\mathrm{U}$ or V-" shaped lesions at the margins of the leaf blade. Under humid conditions, abundant gray sporulation can be observed on the underside of the diseased leaf tissues. Occasionally, shoot blight, blossom blight and dark brown necrosis of the rachis are observed in spring. Shoot blight frequently occurs in grape nurseries. In Chile, $B$. cinerea can infect partially lignified canes after early frosts in autumn, resulting in the development of whitish necrotic lesions with large, irregular, black sclerotia (Latorre, 1986; Latorre and Váquez, 1996).
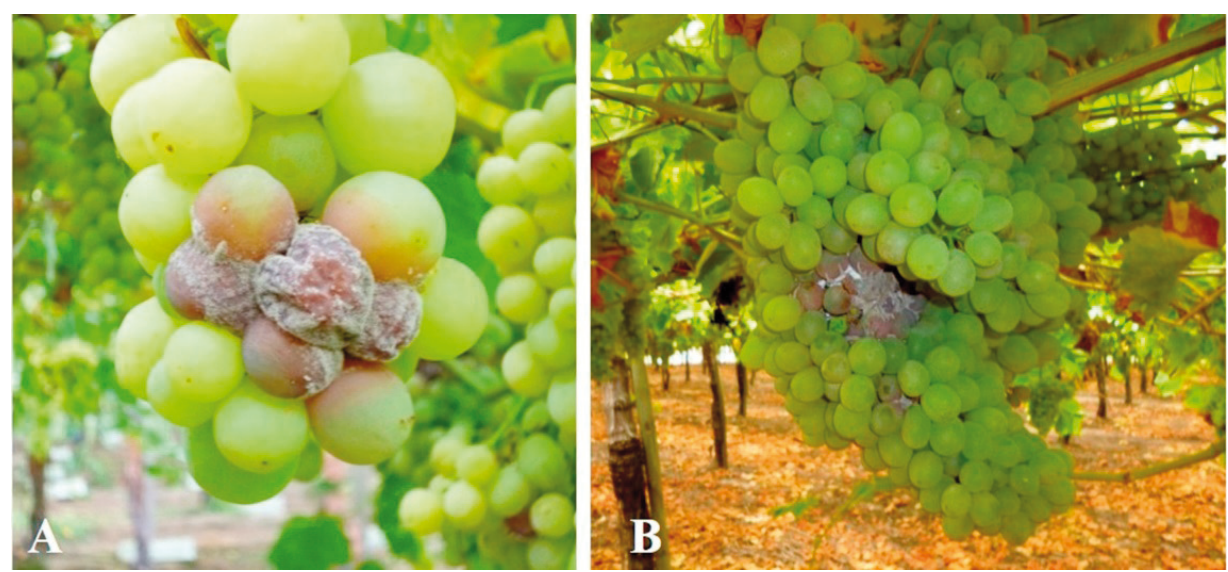

Figure 1. Gray mold symptoms on Thompson Seedless table grapes. A. Reddish brown discoloration, partially dehydrated berries and the presence of gray mold. B. Nest of diseased berries in a very compact cluster. 


\section{The pathogen}

B. cinerea is a ubiquitous fungal pathogen; it is a necrotrophic, haploid, heterothallic ascomycete that attacks over 200 cultivated plant species and numerous wild plants, mostly dicotyledonous plants, worldwide (Elmer and Michailides, 2004). B. cinerea is a major pathogen of fruits, vegetables, ornamentals and forest trees in humid and temperate geographical zones across the world. In addition to grapes, this fungus has been reported on over 60 different cultivated host plants of different taxonomic categories in Chile (Acuña 2008, 2010; Mujica and Vergara, 1980). The capabilities of $B$. cinerea to colonize plants as an endophyte and its importance have been discussed extensively by van Kan et al. (2014).

B. cinerea develops white to gray colonies on potato dextrose agar and other culture medium (Figure 2A), producing filamentous, hyaline, branched and septate mycelia with prominent cell walls. In contrast to other fungi, it contains a low proportion of chitin and a high proportion of neutral sugars and proteins (Cantu et al., 2009). Most isolates produce abundant multinucleate (3-6 nuclei) conidia (macroconidia) which are unicellular, hyaline to slightly colored, smooth, ovoid to ellipsoid, and measure 10-12 $\times$ 8-10 $\mu \mathrm{m}$. Conidia are produced on short sterigmata on the swollen tips of aerial, free, branched conidiophores (Holz et al., 2004) (Figure 2B, C). Espermatia (microconidia) rarely occur in nature; they are small, globose, unicellular, uninucleates that scarcely germinate and never infect plants (Urbasch, 1985). Chlamydospores have been described in $B$. cinerea and can also serve as a survival structure (Holz et al., 2004; Urbasch, 1986).

Black, melanized, elongated or spherical sclerotia measuring 3 to $5 \mathrm{~mm}$ in length are produced under unfavorable conditions in vitro and in planta. Sclerotia play an important role in pathogen survival, dispersal and multiplication. They are commonly found on partially lignified grape shoots that are colonized by $B$. cinerea after early frosts in autumn (Elmer and Michailides, 2004).
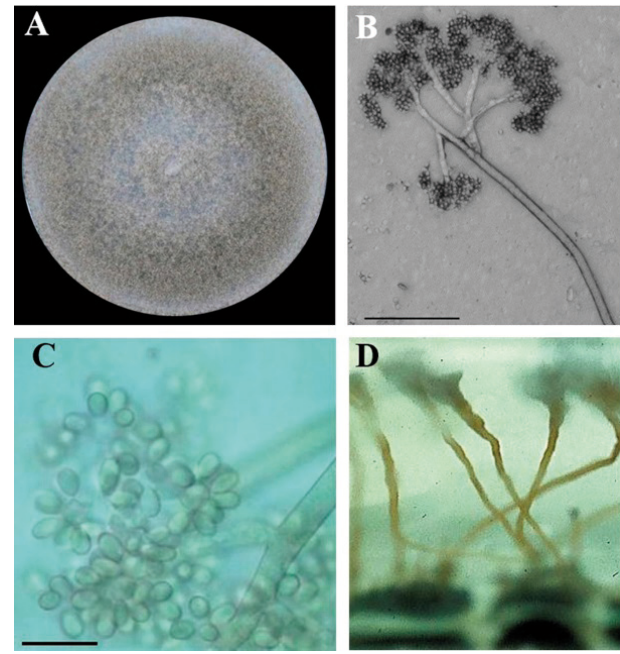

Figure 2. Botrytis cinerea. A. Colony morphology on potato dextrose agar. B. Conidiophore, bar $=100 \mu \mathrm{m}$. C. Conidia, bar $=10 \mu \mathrm{m}$. D. Apothecia.

B. cinerea produces macroscopic, stipitate apothecia that originate from sclerotia (Faretra and Antonacci, 1987) (Figure 2D). Nevertheless, the sexual stage rarely occurs in nature, but apothecia and ascospores can be obtained under controlled laboratory conditions (Faretra and Antonacci, 1987; Faretra et al., 1988).

Two mating types, MAT1-1 and MAT1-2, have been described; they must both be present for ascospore production because most $B$. cinerea isolates are heterothallic. However, homothallic (self-fertile) strains and heterokariotic strains with MAT1-1 and MAT1-2 nuclei have been reported (Faretra et al., 1988; van Kan et al., 2010). The presence of sexually compatible strains has been demonstrated in B. cinerea in Chile (Faretra and Latorre, 2007). Therefore, environmental factors or factors other than the presence of sexual compatibility strains may explain the lack of ascospore production in Chile.

Although the sexual stage rarely occurs in nature, high genetic variability has been reported in populations of $B$. cinerea (Beever and Parkes, 1993; Beever and Weeds, 2004; Diolez et al., 1995, Giraud et al., 1997; Martinez et al., 2003; Muñoz et al., 1999, 2002; Thompson and Latorre, 1999; van der Vlugt-Bergmans et al., 1993). This 
genetic diversity may be explained by (i) cellular aneuploidy (abnormal number of chromosomes in a cell) and heterokaryosis (presence of two or more genetically different nuclei in a cell), (ii) the presence of transposable elements such as Boty and Flipper in the genome, and (iii) spontaneous mutations (Büttner et al., 1994; van Der VlugtBergmans et al., 1993).

Considerable genetic variability based on RAPDPCR or PCR-RFLP analysis was found among Chilean isolates of different origins (Muñoz et al., 1999; Thompson and Latorre, 1999). This genetic variability was later associated with important differences in adhesion, the percent germination on tomato cutin and the ability to colonize tomato leaves, which were demonstrated between genetic groups of Chilean B. cinerea isolates (Cotoras and Silva, 2005).

Based on the presence or absence of the transposons Boty and Flipper in the genome, two sub-populations, transposa and vacuma, have been reported in B. cinerea (Giraud et al., 1997, 1999; Levis et al., 1997). The transposable elements Boty and Flipper were described for the first time by Diolez et al. (1995) and Levis et al. (1997), respectively. Transposa isolates carry Boty and Flipper, whereas both of these transposable elements are absent in vacuma isolates (Giraud et al., 1997). Isolates carrying either Boty or Flipper in the $B$. cinerea genome have also been described (De Miccolis Angelini et al., 2003; Giraud et al., 1999; Muñoz, et al., 2002). In addition, the presence of Boty and Flipper has been found in Chilean populations of $B$. cinerea that affect table grapes, and transposa is the most common isolate (Esterio et al., 2011). However, the presence of transposon elements in $B$. cinerea appears to be independent of the ability of the organism to cause infection (Ciliberti et al., 2015a).

Current evidence suggests that $B$. cinerea is a complex of species that comprises new phylogenetic species, some of which are recently described cryptic species (Fournier et al., 2005; Johnston et al., 2014; Lorenzini and Zapparoli, 2014; Walker et al., 2011; Zhou et al. 2014). Similarly, phylogenetic analysis suggests the presence of cryptic species in B. cinerea from stone fruits in Chile (Ferrada et al., 2014).

B. cinerea sensu stricto (Group II) is predominant in vineyards and includes the transposa and vacuma isolates, whereas Group I occurs in low frequency and includes only vacuma isolates (Albertini et al., 2002; Fournier et al., 2003, 2005; Vercesi et al., 2014). The latter isolates are naturally resistant to fenhexamid and are highly susceptible to fenpropidin and edifenphos (Leroux et al., 2002). However, there is no consensus regarding the relationship between sensitivity to fenhexamid and the presence of Boty and/or Flipper elements in the B. cinerea genome (Ma and Michailides, 2005). Recently, Vercesi et al. (2014) demonstrated that fungicide applications (fenhexamid or cyprodinil+fludioxonil) did not influence the transposon distribution patterns. Isolates belonging to Group I have been identified as B. pseudocinerea sp. nov. (Walker et al., 2011), and these isolates appeared to play a minor role in the gray mold epidemiology of grapevines (Vercesi et al., 2014).

Regarding the functionality and molecular studies of genes, different research groups have extensively studied the genetic and molecular aspects of $B$. cinerea. The genome sequences of $B$. cinerea strains $\mathrm{B} 05.10$ and T4 have been published (Amselem et al., 2011). Additionally, the functionality of the genes involved in the pathogen-host interactions that affect both pathogenicity and virulence have been reported (Baldwin et al., 2006).

\section{Survival, inoculum sources and dispersal}

$B$. cinerea is a necrotrophic, facultative saprophyte that can survive as mycelia and/or sclerotia on grapes (tendrils, cane debris, senescent clusters, and senescent leaf petioles), in numerous alternative hosts and plant residues in the vineyards, 
on other neighboring crops and on some wild plants (Mundy et al., 2012). Depending on the temperature, $B$. cinerea mycelia can survive for up to 30 weeks in grape vine prunings (Elmer and Michailides, 2004).

Conidia can contaminate grape clusters; however, they survive for a short period on grape berry surfaces, particularly if they are exposed to sunlight (Coertze and Holz, 2002; Rotem and Aust, 1991). Nevertheless, long-term (up to 16 weeks) conidial survival has been reported on kiwifruits (Walter et al., 1999).

Therefore, abundant conidia are produced in multiple and very diverse overwintering structures. Conidia are the primary inoculum during flowering and ripening, and it is likely that from the beginning of spring, there is always an abundant and constant availability of viable conidia in the air. The highest conidial concentrations occur on warm humid days after rain (Diaz, et al., 1998; Leyronas and Nicot, 2013; Mundy et al., 2012; Rodríguez-Rajo et al., 2002, 2010; Stepalska, and Wolek, 2005). The conidia are produced in multiple and very diverse substrates (Coertze and Holz, 1999; Corbaz, 1972; Holz et al., 2003; Nair and Nadtotchei, 1987; Williamson et al., 2007).

In Chile, conidia are disseminated locally by wind and water droplets but can also be disseminated by some insects in countries where important insect pests infest grape clusters (Holz et al., 2004). For instance, the larvae of Lobesia botrana can disseminate viable conidia of $B$. cinerea within vineyards (Fermaud and Le Menn, 1989; Pavan et al., 2014). Therefore, the recent detection of $L$. botrana in Chile poses an important epidemiological risk for GM development.

Grape GM can also be disseminated by berry to berry contact due to mycelial growth from a diseased to a healthy berry, which is very frequently observed at harvest and in stored table grapes in Chile. Berry to berry dissemination is favored on highly compact clusters and thin skin cultivars and usually explains the presence of nests of rotted berries (Figure 1B).

\section{Infection}

B. cinerea can infect grape berries during seasonal grape berry development. Immature berries are considered relatively resistant to $B$. cinerea. However, immature berries rapidly increase in susceptibility as the berries mature (Comménil et al., 1997; Deytieux-Belleau et al., 2009; Hill et al., 1981; Mlikota Gabler et al., 2003; Mundy and Beresford, 2007).

Free moisture and temperate are required for infection. Under these conditions, conidia germinate after deposition, hydration and attachment (first stage) to the host surface (Cotoras and Silva, 2005; Doss et al., 1995), forming a single or branched germtube, often with an appressorium at the distal end (Viret et al., 2004). The appressorium facilitates attachment (second stage) and active (direct) penetration of intact host surfaces by means of penetrating hyphae. Current knowledge indicates that a complex enzymatic process, rather than the pressure caused by hyphae penetration, is primarily responsible for active penetration (Tenberge, 2004). Passive (indirect) penetration can occur through natural openings (stomata and lenticels) and wounds (Holz et al., 2003; Kars and van Kan, 2004).

The infection level of GM at maturity is typically the result of (i) latent infections that occur at flowering or during the early stages of berry development and (ii) direct infections during ripining or even later during storage and transit (Mundy et al., 2012; Pezet et al., 2003).

\section{Infection pathways}

At least three infection pathways have been described: 
a. Pedicel end infection through the cap scar or receptacle area at the insertion of the pedicel into the berry. Symptoms start at the berry base as a reddish-brown discoloration and progresses toward the stylar end of the grape berry. This appears to be the most frequent $B$. cinerea infection pathway during blooming (Holz et al., 2003; Keller et al., 2003b; Pezet and Pont, 1986; Viret et al., 2004; Zoffoli et al., 2009).

b. Stylar end infection through the stigmata at bloom. Symptoms appear at the stylar end of mature berries. This pathway appears to be the least frequently observed, and it is almost non-existent in most grape-growing regions (Holz et al., 2003; Pezet and Pont, 1986, Pezet et al., 2003; Viret et al., 2004). Nevertheless, it has been observed in table grapes in Chile (Zoffoli et al., 2009).

c. Lateral infection through berry cheeks. Symptoms begin as small, round, reddish-brown necrotic spots and skin split. This infection pathway is relatively common after rainfall during harvest and is associated with conidia deposition on the surface of the berry. This is the most frequent infection pathway detected during storage of table grapes in Chile, particularly after rainfall events near harvest time (Zoffoli et al., 2009).

\section{Latent infection}

McClellan and Hewitt (1973) were the first to demonstrate the infection of $B$. cinerea through the stigma at the stylar end of the flower. $B$. cinerea remained latent at the stylar end of the grapes, restarting to grow after veraison, causing early rotting at berry maturity. Since then, various reports and further studies have corroborated this finding (Nair and Paker, 1985; Nair et al., 1995; Pezet and Pont, 1986; Pezet et al. 2003; Viret et al., 2004). At present, it is accepted that $B$. cinerea can infect berries at the capfall stage and remain latent in immature grapes. Nevertheless, latent infections can occur during other growth stages of berry development. The final GM incidence results from the cumulative latent infections that occur throughout the growing season (Hill et al., 2014).

The latency of $B$. cinerea in grape berries has been related to constitutive and inducible defense mechanisms (Keller et al., 2003b). Among the latter, the accumulation of phytoalexins (e.g., resveratrol, a stilbene derivate), which are selfdefense secondary metabolites produced in immature grapes (Bavaresco et al., 1997; Flamini et al., 2013; Goetz et al., 1999; van Baarlen et al., 2004; Wang et al., 2013), and the synthesis of PR-proteins have been extensively studied (Elmer and Michailides, 2004; Williamson et al., 2007). The activation of latent infection in mature grape berries has been associated with the weakening of the natural defense barriers and the decline in phytoalexins during repining in susceptible grape cultivars (Bais et al., 2000; Goetz et al., 1999; Jeandet et al., 1991; Keller et al., 2003b; Pezet et al., 2003; Prusky and Lichter, 2007).

\section{Colonization of senescent tissues}

B. cinerea colonizes floral debris, such as senescent stamens, caliptra and aborted berries, between bloom and fruit set, remaining quiescent until later in the growing season. This infected floral debris is often retained in the grape clusters and provides inoculum for berry infection during ripening or even later during storage and transit (Calvo-Garrido et al., 2014a; Jacometti et al., 2010; Keller et al., 2003; Latorre and Vásquez, 1996; Latorre et al., 2001; Nair, et al., 1988, 1995; Pezet and Pont, 1986; Viret et al., 2004; Wolf et al., 1997). It is possible that the abundance of pollen and stigma exudates during flowering increases the level of colonization of floral debris (McClellan and Hewitt, 1973).

\section{Predisposing factors}

Predisposing factors are genetic (physiological and anatomical), physical (wounds), environmental 
(climate and weather conditions) and agronomic (cultural practices), all of which can render grapes more susceptible to or favor the development of the pathogen by enhancing GM severity. Knowledge of these factors has been very important in establishing appropriate control strategies.

\section{Genetic factors}

In addition to cluster compactness, several genetic factors, i.e., morphological, anatomical, and chemical features of the berry skin, predispose berries to $B$. cinerea infection in nature. These factors include thin berry cuticles (Comménil et al., 1997; Zoffoli et al., 2009), low epicuticular wax content (Marois et al., 1986, 1987; Percival et al., 1993), high berry porosity (Blaich et al., 1984; Mlikota Gabler et al., 2003), and the number and thickness of the skin cell layers of the berry (Mlikota Gabler et al., 2003). A sensor that enables the measurement of the electrical impedance of the grape berry cuticles and their epicuticular waxes has been developed as a reliable method to estimate the degree of berry susceptibility to GM and could be a valuable tool for genetic analysis in breeding programs (Herzog et al., 2015).

\section{Physical factors}

The nature of physical factors can be biotic (e.g., insects, birds, snails, other plant pathogens) and abiotic (e.g., rain, hail, frost, sunburn, rapid water intake) (Becker and Knoche, 2012a, b; Coertze and Holz, 1999; Fermaud and Le Menn, 1989; Nair, et al., 1988). These factors induce fresh wounds in the skin that are very often microscopic cracks, which prevent the action of the cuticle as a physical barrier to penetration. For instance, on stored table grapes, the overuse of sulfur dioxide can induce hairline microcracks which facilitate B. cinerea infection of grapes (Zoffoli et al., 2008). Suberized berry injuries do not serve as infection sites (Coertze and Holz, 2002; Elad and Evensen, 1995).

\section{Environmental factors}

It is widely accepted that microclimate conditions within the grape canopy, specifically temperature and humidity (relative humidity and free moisture), are key factors for B. cinerea infection (Broome et al., 1995; English et al., 1989; Nair and Allen, 1993; Steel et al., 2011; Thomas et al., 1988; Valdés-Gómez et al., 2008).

Since the early work of Nelson (1951), several studies have been published regarding the relationship between GM infection and ambient parameters. Currently, it is accepted that conidia germinate between 0 and $30^{\circ} \mathrm{C}$ with optimum temperatures between 20 and $25^{\circ} \mathrm{C}$. At $30^{\circ} \mathrm{C}$, conidia are not produced, and conidial germination is arrested. At optimal temperatures, germination occurs within $3 \mathrm{~h}$. Numerous studies have demonstrated that free moisture is essential for conidial germination and berry infection (Broome et al., 1995; Ciliberti et al., 2015b; Coertze and Holz, 2002; Latorre and Rioja, 2002; Latorre et al., 2002; Nair and Allen, 1993; Steel et al., 2011; Thomas et al., 1988).

At optimum temperature, the estimated incubation period for flower infection on Cabernet Sauvignon grapes was considerably shorter $(<1.3 \mathrm{~h})$ than the incubation period estimated for berry infection (13.9 h) (Nair and Allen, 1993). Latorre et al. (2002) worked with Thompson Seedless table grapes and determined an incubation period of less than 24 h at $20{ }^{\circ} \mathrm{C}$ for flower infection and $48 \mathrm{~h}$ at $20{ }^{\circ} \mathrm{C}$ for berry infection. The incubation period was shorter for berry infection of Thompson Seedless than Flame Seedless table grapes (Latorre et al., 2002). Therefore, berry infection appears to be dependent on the grape cultivar.

In addition to temperature and relative humidity, wind speed affects aerial mycelia and conidia production. These three factors determine the evaporative potential within the grape canopy, which reflects the capacity of the air to evaporate water (English et al., 1990; Thomas et al., 1988). Therefore, maximum production of conidia oc- 
curs when the evaporative potential fluctuates between 0.05 and $0.15 \mathrm{~g} \cdot \mathrm{h}^{-1}$ of water, and aerial mycelia are produced below $0.25 \mathrm{~g} \cdot \mathrm{h}^{-1}$ of water. At $21{ }^{\circ} \mathrm{C}$, abundant conidia were produced at a $94 \%$ relative humidity and $0.6 \mathrm{~m} \cdot \mathrm{sec}^{-1}$ wind speed (Thomas et al., 1988). Aerial mycelia were produced at $21{ }^{\circ} \mathrm{C}, 94 \%$ relative humidity and 0 $\mathrm{m} \cdot \mathrm{sec}^{-1}$ wind speed, but no aerial mycelia were developed at a $69 \%$ relative humidity and wind speed $>0 \mathrm{~m} \cdot \mathrm{sec}^{-1}$ (Thomas et al., 1988).

Berries that are exposed to sunlight, particularly UV-B light, produce thicker wax layers than berries under shaded conditions (Keller et al., 2003a). Hence, berries exposed to sunlight usually have a thicker cuticle, which reduces GM incidence and severity (Percival et al., 1993). Furthermore, UV light has a strong germicidal effect against the conidia of B. cinerea (Latorre et al., 2012).

\section{Agronomic factors}

Agronomic factors predispose grapes to GM infection because they essentially alter the microclimate conditions within the grape canopy. These factors include canopy density and leaf removal after flowering (English et al., 1989; Gubler et al., 1987; Molitor et al., 2011; ValdésGómez et al., 2008; Zoecklein et al., 1992), cluster compactness and thinning (Barbetti, 1980; Ferree et al., 2003; Hed et al., 2009; Marois et al., 1986; Molitor et al., 2011; Percival et al., 1994; Smithyman et al., 1998; Vail and Marois, 1991), nutrition and fertilization (Mundy, 2008), grape training systems (de Bem et al., 2015) and winter pruning (Savage and Sall, 1984).

\section{Forecasting system}

The use of forecasting systems to predict GM infection conditions can be a useful decision support tool to complement integrated disease management strategies. Forecasting systems allow the reduction of unnecessary fungicide applications, restrict- ing them to periods that are conducive to disease development. Models to predict conditions for $B$. cinerea infection in grapes, which are based on environmental conditions (Broome et al., 1995; González-Domínguez et. al., 2015; Kim et al., 2007; Latorre et al., 2002; Nair and Allen, 1993; Shtienberg, 2004; Shtienberg and Elad, 1997) and inoculum concentration and their dynamics (Carisse et al., 2014; Fernández-González et $a l ., 2012)$, have been developed and proposed to predict the risk of GM infection. For example, Broome et al. (1995) developed a predictive model to determine the risk of $B$. cinerea infection on grapes. This model estimates the infection risk as a function of the temperature and duration of wetness. Thus, farmers have a useful tool to establish the need for a fungicide treatment. This model was successfully validated on a commercial basis in Chile, and it has been used by farmers as a guide in control decisions.

\section{Pathogen detection}

The detection and quantification of $B$. cinerea is highly desirable for research and disease management purposes. Based on this information, it would be possible to estimate the potential risk of GM in lots of table grapes, saving only lots with a low infection risk for long storage periods. Similarly, it would aid in the discrimination of wine grape lots by price penalizing or rejecting lots above a threshold value of GM prevalence and severity. Several detection methods have been tested (Dewey and Yohalem, 2004), including the following: (i) Direct plating on selective or semi-selective agar media (Kerssies, 1990) or agar media amended with $1 \%$ (v/v) Igepal (Alltech Associates, Inc. Illinois) used as a colony growth restrictor (Latorre et al., 2001, 2011); (ii) induction of tissue senescence using paraquat or freezing as a means of promoting the development of $B$. cinerea on the culture medium (Holz et al., 2003); (iii) enzyme-linked immunosorbent assays (ELISAs) employing specific monoclonal antibodies (Fernández-Baldo et al., 2011; Obanor et al., 2004; 
Ricker et al., 1991; Ruiz and Ruffner, 2002); (iv) methods based on nucleic acid detection, such as polymerase chain reaction (PCR) (Gindro et al., 2014), reverse transcription PCR (RT-PCR) (Choquer et al., 2003) and quantitative real-time PCR (qPCR) (Diguta et al., 2010; Sanzani et al., 2012); and (v) autofluorescence response (Belanger et al., 2011). Other detection techniques, such as the incubation of berry samples under conditions conducive for GM development, adapted from Harvey (1955), have been used by Chilean table grape export companies to estimate the potential risk of GM during storage (Zoffoli et al., 2009).

A disease assessment key and assessment training software (Bunch Rot Assessment Trainer, BRAT) were developed based on disease incidence and severity relationships to improve the accuracy, repeatability and speed of visual GM assessment, which is commonly conducted when wine grape lots are received by the wineries (Hill et al., 2010).

\section{Integrated disease management}

The considerable increase in the understanding of $B$. cinerea biology and GM epidemiology has resulted in important improvements in grape GM control. It is generally accepted that integrated disease management is the only possible strategy to achieve the GM threshold tolerance at harvest, which is below $0.5 \%$ and $2.0 \%$ for table and wine grapes, respectively. At present, integrated disease management mainly includes cultural and chemical control, but the use of biological control (Montealegre and Pérez, 2014) and the search for resistant cultivars (Rubio et al., 2015) is gaining importance in conventional and organic grape production.

The progression of the grape GM epidemic over time follows an exponential relationship $y=x_{0} e^{r t}$, where $\mathrm{y}=$ final disease level; $\mathrm{x}_{0}=$ initial disease level (which is associated with the inoculum load); $\mathrm{t}=$ time and $\mathrm{r}=$ disease infection rate (Madden, 1980).
The difficulties associated with the control of GM can be explained by the exponential nature of GM progression during the beginning of the epidemic (Beresford et al., 2006; Madden, 1980) and by the relatively high infection rates that usually characterize this disease under optimal environmental conditions. For example, in New Zealand vineyards, it has been estimated that GM severity can increase at a rate of $1-2 \%$ per day near harvest time (Evans, 2010).

Integrated disease management against grape GM includes the use of several control measures (Evans, 2010), some of which reduce the initial inoculum $\left(x_{0}\right)$, whereas others are oriented toward lowering the disease infection rate $(r)$. Regarding the pathogen, the epidemiological factors and the exponential nature of the disease progression curve that characterizes grape GM, the major contribution is usually achieved when control measures are oriented to reduce $r$ rather than $x_{0}$. Therefore, all control measures contribute to final GM control, but in different proportions. Consequently, the selection of a control measure can vary among different geographical areas according to the purpose of the grape production and the cost benefit relationship (Evans, 2010).

\section{Cultural control}

Canopy management. Canopy management practices are viticultural techniques that modify the canopy characteristics with the aim of improving yield, quality and vigor by facilitating mechanization, increasing the efficiency of pesticides and other agricultural chemicals, or preventing grape diseases (Smart et al., 1990). Among the cultural practices, the removal of senescent debris and infected pruned wood reduces the initial inoculum $\left(x_{0}\right)$. In addition, avoiding berry wounds, cluster elongation, cluster thinning, cluster removal, heading, leaf removal and shoot thinning can affect the canopy microclimate and limit the conditions that are conducive to GM in the cluster zone, significantly 
reducing the infection rate $(r)$, often as much as fungicide treatments.

Leaf removal. Numerous studies have demonstrated the effect of leaf removal on GM control. Typically, one to three basal leaves per shoot in the fruit zone are manually or mechanically removed (Gubler et al., 1991). At present, leaf removal is used worldwide to manage high-density canopies by enhancing light exposure and airflow through and around the cluster zones and by increasing wind speed, evaporative potential and UV exposure (Bettiga et al., 1986; English et al., 1989,1990,1993; Ferree et al., 2003; Gubler et al., 1987,1991; Hed et al., 2015; Latorre, 1986; Molitor et al., 2011; Poni et al. 2006; Thomas et al., 1988; Zoecklein et al., 1992). The efficiency of leaf removal on GM control depends, among other factors, on the seasonal weather conditions. Leaf removal is highly efficient in relatively dry seasons but is insufficient to obtain a good degree of GM control in very wet seasons. However, in very wet seasons, leaf removal enhances the efficacy of fungicide treatment (English et al., 1993).

Leaf removal decreases $B$. cinerea and other epiphytic fungi commonly found on grape berries (Duncan et al., 1995). Additionally, it can stimulate phytoalexin, as well as epicuticular wax and cuticle production, in exposed berries and consequently prevent GM infections (Percival et al., 1993).

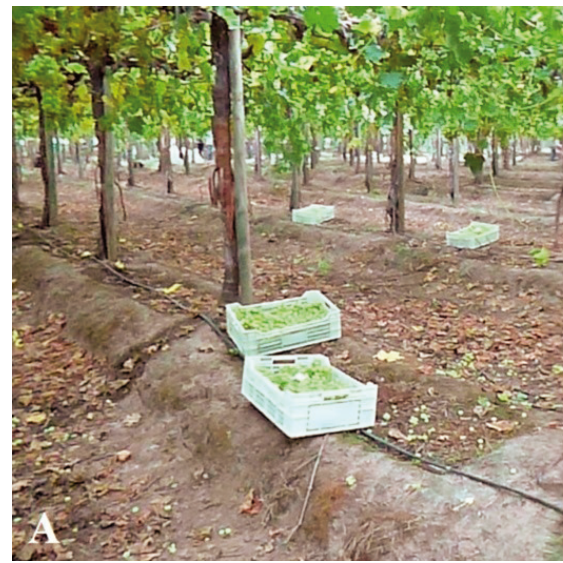

It has been suggested that the evaporative potential within the vine canopy can provide a simple means of determining the canopy opening and the drying conditions resulting from leaf removal (English et al., 1993). The evaporative potential within a grape canopy is inversely related to canopy density and $1 \mathrm{~mL} \cdot \mathrm{h}^{-1}$ has been suggested to be the minimum evaporative potential to diminish GM (English et al., 1993). However, further research is needed to develop this technique and validate it under different grape training systems and different agro-ecological conditions.

Heading and shoot removal. Heading entails pruning off the over-hanging current season growth (Bettiga et al., 1986; Savage and Sall, 1982), and shoot removal entails the removal of an excessive number of shoots per vine to modify microclimate conditions within the grape canopy, which reduces the conditions conducive to GM. These viticultural practices increase airflow and sunlight penetration within the grape canopy and are especially important for table grapes trained as Pergola, which often have a very dense foliage canopy (Figure 3) (Zoecklein et al., 1992).

Cluster removal and cluster thinning. In most table grape cultivars, cluster removal and cluster thinning are essential for obtaining quality fruit to satisfy market demand. These viticultural practices are also of paramount importance to

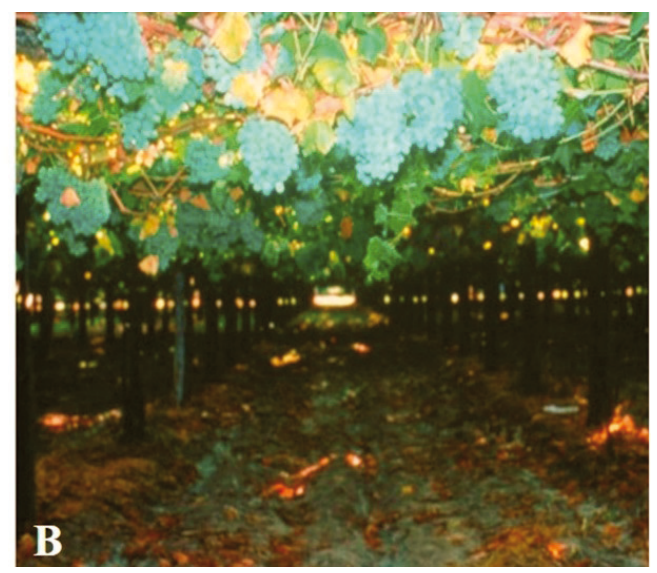

Figure 3. Thompson Seedless table grapes trained as Pergola. A. A general view at harvest time. B. A dense canopy interfering light penetration and air flow around clusters. 
prevent severe GM. Cluster removal prevents over cropping and bunch crowding at harvest, preventing a delay in cluster maturation and assuring high quality berries. Cluster thinning prevents compactness, improves airflow within clusters, and limits berry to berry contact, which restricts cuticle development at the contact points and prevents berry split in the interior of the clusters. Furthermore, fungicide spray cover becomes imperfect as cluster compactness increases (Hed et al., 2009; Marois et al., 1986; Tardaguila et al., 2008; Vail and Marois, 1991; Zoecklein et al., 1992). Additionally, it has been demonstrated that cluster thinning increases the total resveratrol level (Prajitna et al., 2007).

Cluster elongation. In some wine grapes, cluster elongation, which can be achieved with the use of growth regulators (e.g., GA3 gibberellin, prohexadione-Ca), can reduce cluster compactness, improve airflow and considerably reduce microclimate conditions within the grape canopy that favor GM development (Ferree et al., 2003; Hed et al., 2011, 2015; Molitor et al., 2011; Pearson and Riegel, 1983). However, this technique has not been used commercially in Chile, and its use appears to be quite limited in other countries.

Removal of senescent debris. It has been demonstrated that the physical removal of senescent tissues (e.g., floral debris, aborted berries, leaves) retained on the clusters can partially reduce GM incidence and severity by approximately $30 \%$. However, the GM reduction can vary with other epidemiological factors. Physical removal of senescent debris can be achieved with high air speeds using air blast sprayers or backpack blowers (Jermini et al., 1986; Wolf et al., 1997).

\section{Nutrition and fertilization}

Plant nutrition and fertilization are important predisposing factors that affect the susceptibility of grapes to GM infection and consequently affect the disease infection rate $(r)$ rather than the initial inoculum $\left(x_{0}\right)$. Nitrogen and calcium are the best documented nutrients in connection with their effects on grape GM.

Several studies have reported that high nitrogen nutrition predisposes berries to GM infections (Keller et al., 2001; Mundy, 2008; Valdés-Gómez et al., 2008). High nitrogen promotes excessive vegetative growth and vigor, which enhance canopy density, thus generating a microclimate within the grape canopy that favors GM. In addition, high nitrogen levels delay berry ripening, increase cluster compactness and reduce the thickness of the berry cuticle (Valdés-Gómez et al., 2008; Keller et al., 2001).

Calcium is an essential mineral element that plays an important role in enzymatic and hormonal processes, preserving the integrity of membranes and cell walls, improving the storage quality of table grapes and other fruits and acting in plant cell signaling (Sanders et al., 1999). In general, increasing the calcium content of grape berries, particularly the skin, lowers berry susceptibility to $B$. cinerea infection (Chardonnet and Donèche, 1995; Miceli et al., 1999). Furthermore, it has been reported that some calcium salts exhibit inhibitory activity against $B$. cinerea in vitro and/or in vivo by inhibiting the polygalacturonase enzyme, spore germination and germ tube elongation (AlQurashi and Awad, 2013; Chervin et al., 2009; Nigro et al., 2006).

\section{Grapevine training system}

Training systems that promote a high canopy density tend to create favorable microclimate conditions around clusters, exposing grapes to longer periods of wetness, and thus fostering GM (Elmer and Michailides, 2004; Phillips et al., 1990). Therefore, to reduce GM severity, training systems that favor airflow around clusters should be preferred. However, the Pergola system (Figure 3 ), which is a high trellis system with a 2-m high horizontal plane of vegetation 
that favors GM severity, is widely used for table grape production in Chile because it promotes high yield and quality.

\section{Irrigation}

Most grape production in Chile is under irrigation, which is essential to fulfill the water requirements of grapes during the spring and summer months. The oldest vineyards are surface irrigated (flood and furrow irrigation systems), whereas most of the new vineyards use drip irrigation systems. Regardless of the system used, irrigation has been considered to be predisposing factor for GM development because it increases humidity around the clusters and, in combination with nitrogen fertilization, promotes shoot vigor, foliage growth, cluster compactness, and delays fruit maturity (Valdés-Gómez et al., 2008).

\section{Biological control}

Biological control (biocontrol) has been defined as the use of an antagonistic microorganism to control a plant disease. Following this approach, a number of microorganisms have been reported as antagonists of $B$. cinerea in vitro; they have been suggested as potential agents to control GM on grapes and other crops (Elad and Stewart, 2004; Elmer and Reglinski, 2006; Jacometti et al., 2010).

For example, there are a large number of filamentous fungi and Oomycetes, such as species of Epicoccum, Gliocladium (Clonostachy) Trichoderma, Pythium and Ulocladium; yeasts, such as species of the genera Acremonium, Aerobasidium, Candida, Cryptococcus, Debaryomyces, Hanseniaspora, Issatchenkia, Pichia, Saccharomyces, Schizosaccharomyces, and Torulaspora; and some bacterial species belonging to Bacillus, Brevibacillus, Pseudomonas and Serratia (Elmer and Reglinski, 2006; Vargas et al., 2012) that have been identified as potential control agents. However, very few antagonists have demonstrated activity under field conditions and even fewer have been formulated and used commercially against grape GM (Elmer and Reglinski, 2006; Nally et al., 2012).

There is a long history of studies on Trichoderma spp. against $B$. cinerea, both in the laboratory and in the vineyard. Isolate T39 of T. harzianum was the first to be formulated as Trichodex (Makhteshim-Agan, Israel) (Elmer and Reglinski, 2006). The use of isolate T39 resulted in partial control, which was significantly different ( $p<$ 0.05 ) from untreated controls and equal to or less than the control achieved using vinclozolin (Ronilan $50 \mathrm{WP}, 1.5 \mathrm{~kg} \mathrm{ha}^{-1}$ ) but similar to the control achieved using captan (Captan 80 WP, 4 $\mathrm{kg} \mathrm{ha}^{-1}$ ) on table grapes infected with $B$. cinerea (Harman et al., 1996; Latorre et al., 1997). The Trichoderma population on table grape flowers and clusters decreased relatively rapidly, suggesting a short survival in the grape canopy (Latorre et al., 1997). Based on these and several other reports, the degree of control provided under field conditions seems to be adequate only under low to moderate disease pressure (Latorre, 2013; Montealegre and Perez, 2014).

The use of species of Bacillus, including B. circulans, $B$. brevis and $B$. subtilis as antagonists against $B$. cinerea has been documented under laboratory and field conditions (Ben Maachia et al., 2015; Elmer and Reglinski, 2006). B. subtilis strain QST-713, which is formulated as Serenade (Agra Quest, USA), provided good GM control under field conditions in Chile (Esterio et al., 2000). In B. subtilis, cyclic lipopeptides (surfactins, iturins and fengycins) have been involved in activating plant defenses; some of these cyclic lipopeptides can act directly against B. cinerea (Farace et al., 2015).

Biocontrol agents exert their antagonistic action as a result of several biological mechanisms acting alone or combined, which may include competition for nutrients and space, the production of inhibitory metabolites, the induction of biological processes and parasitism (El Ghaouth et al., 2003; Elmer and Reglinski, 2006). Biocontrol agents 
have been used to protect grape berries, i.e., as a replacement for fungicide treatments; therefore, they are used to reduce the infection rate $(r)$. However, there is no consensus on whether this is the best approach.

At present, biological control is recognized as a complex process that should take into consideration the pathogen, the host and the environment, as well as their interactions (Droby et al., 2009). Following this concept, several new approaches to strengthen biological control are being studied. These approaches include the combination of two or more antagonistic strains, the induction of natural biological processes (e.g., inducing systemic resistance) (El Ghaouth et al., 2003; Reglinski et $a l ., 2005)$, the use of natural antimicrobial products (e.g., chitosan, lysozyme) and plant resistance (Calvo-Garrido et al., 2013, 2014b; Droby et al., 2009). In addition, the identification and use of yeasts, which are normal components on the surface of grape berries, have been studied for their capacity as biocontrol agents (Nally et al., 2012; Parafati et al., 2015; Vargas et al., 2012). A better understanding of the microbial ecology of grape berries will help to improve studies to determine the best biocontrol alternative (Barata et al., 2012). Overall, it is expected that these new approaches in the study of biological control can improve the efficacy and consistency of new products, making biocontrol a more reliable strategy to prevent GM in grapes and other crops.

Finally, the presence of dsRNA mycoviruses has been described in B. cinerea in Chile and other countries. Considering that some of these mycoviruses are associated with hypovirulence, there is considerable interest in their study and eventual use as biocontrol agents (Castro et al., 2003; Howitt et al., 1995; Vilches and Castillo, 1997).

\section{Chemical control}

Chemical treatment is still a very important control strategy against grape GM; its use is often required for a high degree of grape GM control. The foliar application of fungicides is used to protect the grape cluster and reduce the infection rate $(r)$ as much as possible during the growing season. Nevertheless, the use of fungicides is increasingly restricted because of major environmental and human health concerns (Komárek et al., 2010) and because of the frequent development of resistant strains of B. cinerea (De Miccolis Angelini et al., 2014; Latorre and Torres, 2012; Leroux, 2004; Leroux et al., 2002).

\section{Fungicide groups}

At present, highly effective synthetic fungicides with different biochemical modes of action are available against grape GM (FRAC, 2015). Most of the recently developed fungicides are site-specific compounds with a single-site mode of action while older fungicides are compounds with multi-site modes of action.

Currently, chemical control is mainly based on the use of fungicides with a single-site mode of action. These fungicides belong to the following groups (FRAC, 2015; Leroux, 2004): i. Anilinopyrimidines (e.g., cyprodinil, mepanipyrim, pyrimethanil); ii. Succinate dehydrogenase inhibitors (SDHI) (e.g., boscalid, penthiopyrad); iii. Demethylation inhibitors (DMI), Class I (e.g., tebuconazole); iv. DMI, Class III, hydroxyanilides (e.g., fenhexamid); v. Dicarboximides (e.g., iprodione); vi. 2,6-Dinitroanilines (e.g., fluazinam); vii. Phenylpyrroles (e.g., fludioxonil); and viii. Quinone outside inhibitors (QoI) (strobilurines) (e.g., azoxystrobin). Benzimidazoles are still available, but because of resistance problems, they are no longer used against grape GM.

Fungicides with multi-site modes of action, such as phthalimide derivatives (captan and folpet), sulfamide derivatives (dichlofluanid and tolyfluanid) and chloronitrile derivatives (chlorothalonil), are still used against $B$. cinerea (Leroux, 2004). These fungicides have protective action, and with few 
exceptions, resistance rarely occurs (Pollastro et al., 1996).

\section{Fungicide timing}

Fungicides against $B$. cinerea applied as preinfection (protective) treatments allow better control efficiency than post-infection (curative) treatments. The post-infection activity of most fungicides is short, usually less than 24 to $48 \mathrm{~h}$ (Serey et al., 2007; Smilanick et al., 2010).

Field studies have delimited the grape growth stages at which fungicides should be applied to obtain a high degree of GM control. Farmers commonly use specific and very effective fungicides only at the most critical grape growth stages. In Chile and other countries, the fungicide application programs most commonly consist of three to four preventive fungicide applications, which include one fungicide spray at flowering, bunch closure, veraison and pre-harvest (Calvo-Garrido et al., 2014a; Edder et al., 2009; Latorre et al., 2001; Petit et al., 2010). However, the relative importance of these stages can vary under different agro-ecological conditions and with grape management and cultivars.

In contrast to reports that question the value of flowering applications (De Kock and Holz, 1994), fungicides sprayed at flowering significantly reduced GM incidence and severity on Thompson Seedless and Red Globe table grapes at harvest in Chile, but fungicide efficacy was lower at flowering than between veraison and harvest (Latorre et al., 2001). Recently, Calvo-Garrido et al. (2014a) concluded that the most effective fungicide treatment consisted of applications at flowering, with and without pre-bunch closure, or after veraison applications. Nevertheless, additional sprays at pre-bunch closure or during the late season were needed when conditions were highly conducive to GM infection.

During flowering, fungicide treatments are aimed at reducing the latent infection and colonization of senescent tissues; however, fungicide treatments applied after veraison protect berries against late GM infections and often provide post-harvest protection for table grapes (Franck et al., 2005; Smilanick et al., 2010).

\section{Fungicide resistance}

B. cinerea is considered to be a high resistance risk pathogen because it produces abundant conidia as a primary inoculum, which is then efficiently disseminated. In addition, this fungus has a high genetic variability and wide host range; thus, a high number of fungicide applications are commonly required for control because of the polycyclic nature of GM (Brent and Hollomon, 2007a, b; Latorre and Torres, 2012; Myresiotis et al., 2007).

To control GM, fungicides with single- and multisite modes of action are available; these correlate with a moderate to high and a low risk of the development of resistant strains of $B$. cinerea, respectively. Cross-resistance to fungicides with the same mode of biochemical action has been extensively described (Leroux, 2004). Therefore, to avoid resistance, fungicides with different biochemical modes of action should be alternated or combined each growing season. Furthermore, the use of fungicides with a single-site mode of action is frequently limited to one or two applications per season (Brent and Hollomon, 2007a).

Resistance to fungicides with a single-site mode of action has been found in Chilean vineyards (Latorre et al., 1994, 2002; Carreño and Alvarez, 1990; Esterio et al., 2007, 2015; Latorre et al., 2002; Piqueras et al., 2014; Thompson and Latorre, 1999). Recently, multiple resistance has been reported in $B$. cinerea in grapes in Chile (Latorre and Torres, 2012) and other countries (De Miccolis Angelini et al., 2014; Leroch et al., 2011). This reflects the danger of the intensive use of fungicides against GM and reinforces the fact that fungicide resistance is a serious threat to the grape industry. 


\section{Postharvest gray mold control on table grapes}

B. cinerea causes substantial postharvest decay on table grapes. Even a single infected berry within a table grape package can cause severe losses if control strategies are not taken. Considering that the primary inoculum always comes from the vineyard, a thorough control strategy should always start in the field. Furthermore, fungicide residues of certain fungicides applied just before harvest can also protect grapes during storage and transportation (Smilanick et al., 2010). In stored grapes, refrigeration $\left(-0.5\right.$ to $\left.0.5^{\circ} \mathrm{C}\right)$ and the use of sulfur dioxide are the strategies currently used to prevent GM in stored table grapes (Franck et al., 2005).

\section{Conclusions}

Grape GM caused by $B$. cinerea is a major fungal disease affecting grapes and other crops worldwide. The polycyclic nature of the GM epidemic, the abundant production of $B$. cinerea inoculum and the efficient dissemination mechanisms, as well as the wide host range and high genetic variability of
B. cinerea, explain the difficulties encountered in attempting to control GM. In Chile, GM has limited table grape production to geographical zones that are less prone to infection. It is frequently the cause of important losses at destination markets in the United States, Europe or Asia. Similarly, GM has caused considerable yield losses and has reduced the quality of wine grapes worldwide. The level of GM infection in vineyards results from the interaction of various factors, such as the host, pathogen and environmental conditions. In the last two decades, tremendous progress has been made toward understanding pathogen biology and epidemiology, as well as toward improving control strategies. At the same time, the incorporation of molecular tools to study the pathogen has resulted in important genetic contributions and the development of new control opportunities. Today, there is considerable concern over the rapid development of $B$. cinerea strains that are resistant to fungicides, as well as the use of fungicides in general, because of environmental and toxicological considerations. Therefore, new knowledge is essential to establish novel sustainable control strategies that allow more effective control and reduced use of fungicides.

\section{Resumen}

B.A. Latorre, K. Elfar y E.E. Ferrada. 2015. Pudrición gris, causada por Botrytis cinerea, limita la producción de vid en Chile. Cien. Inv. Agr. 42(3): 305-330. La pudrición gris (PG) causada por Botrytis cinerea, es una de las principales enfermedades de la vid (Vitis vinifera) que limita la producción y reduce los rendimientos y la calidad de la fruta en zonas templadas y húmedas a nivel mundial. $B$. cinerea es un hongo necrótrofo que ataca órganos aéreos no lignificados de la vid, siendo las bayas altamente susceptibles durante la maduración. La naturaleza policíclica y el desarrollo exponencial de las epidemias de PG, junto con la abundancia de inóculo, la eficiente dispersión más el amplio rango de hospederos y gran variabilidad genética que presenta $B$. cinerea, explican las dificultades para lograr un control satisfactorio. Ante lo cual se hace necesario realizar una estrategia de control integrado que combine medias de control cultural y químico. Estas medidas pueden estar orientadas a reducir el inoculo inicial o la tasa de progreso de la enfermedad, siendo las medidas de control destinadas a reducir la tasa de progreso las que más aporta al control de PG. En las últimas décadas se han producido importantes progresos en el conocimiento de la compleja biología de este patógeno y de los aspectos epidemiológicos de la PG. Esto ha permitido mejorar las estrategias de control logrando alternativas más efectivas y sustentables. En este artículo se revisan los aportes científicos recientes realizados en relación con la PG de la vid, teniendo especial énfasis en la situación del viñedo chileno.

Palabras clave: Botryotinia fuckeliana, pudrición gris, epidemiología, fungicidas, necrótrofo, Vitis vinifera. 


\section{References}

Acuña, R. 2008. Compendio de Fitopatógenos de Cultivos Agrícolas en Chile. Servicio Agrícola y Ganadero, Ministerio de Agricultura, Gobierno de Chile. Santiago, Chile. 122 pp.

Acuña, R. 2010. Compendio de Bacterias y Hongos de Frutales y Vides en Chile. Servicio Agrícola y Ganadero, Ministerio de Agricultura, Gobierno de Chile. Santiago, Chile. 150 pp.

Albertini, C., G. Thébaud, E. Fournier, and P. Leroux. 2002. Eburicol 14 $\alpha$-demethylase gene (cyp 51) polymorphism and speciation in Botrytis cinerea. Mycol. Res. 106:1171-1178.

Al-Qurashi, A.D., and M.A. Awad. 2013. Effect of pre-harvest calcium chloride and ethanol spray on quality of 'El-Bayadi' table grapes during storage Vitis 52:61-67.

Amselem, J., C.A. Cuomo, J.A.L. van Kan, M. Viaud, E.P. Benito, A. Couloux, P.M. Coutinho, R.P. de Vries, P.S. Dyer, S. Fillinger, E. Fournier, L. Gout, M. Hahn, L. Kohn, ..., and M. Dickman. 2011. Genomic analysis of the necrotrophic fungal pathogens Sclerotinia sclerotiorum and Botrytis cinerea. PLOS Genetics 7(8): e10022300.

Bais, A.J., P.J. Murphy, and I. Dry. 2000. The molecular regulation of stilbene phytoalexin biosynthesis in Vitis vinifera during grape berry development. Aust. J. Plant Physiol. 27:425-433.

Baldwin, T.K., R. Winnenburg, M. Urban, C. Rawlings, J. Koehler, and K.E. Hammond-Kosack. 2006. The pathogen-host interactions database (PHI-base) provides insights into generic and novel themes of pathogenicity. Mol. Plant-Microbe Interact. 19:1451-1462.

Barata, A., M. Malfeito-Ferreira, and V.B. Loureiro. 2012. The microbiology ecology of wine grape berries. Int. J. Food Microbiol. 153:243-259.

Barbetti, M.J. 1980. Reductions in bunch rot in Rhine Riesling grapes from bunch thinning. Aust. Plant Pathol. 9:8-10.

Bavaresco, L., D. Petegolli, E. Cantu, M. Fregoni, G. Chiusa, and M. Trevisan. 1997. Elicitation and accumulation of stilbene phytoalexins in grape berries infected by Botrytis cinerea. Vitis 36:77-83.
Becker, T., and M. Knoche. 2012a. Deposition, strain, and microcracking of the cuticle in developing 'Riesling' grape berries. Vitis 51:1-6.

Becker, T., and M. Knoche. 2012b. Water induces microcracks in the grape berry cuticle. Vitis 51:141-142.

Beever, R.E., and S.L. Parkes. 1993. Mating behaviour and genetics of fungicide resistance of Botrytis cinerea in New Zealand. N.Z. J. Crop and Hortic.Sci. 21:3003-310.

Beever, R.E., and P.L. Weeds. 2004. Taxonomy and genetic variation of Botrytis and Botryotinia. Pages 29-52. In: Y. Elad, B. Williamson, P. Tudzynski, and N. Delen (eds.). Botrytis: Biology, Pathology and Control. Kluwer Academic Publishers. Dordrecht. The Netherlands. 428 pp.

Belanger, M.C., J.M. Roger, P. Cartolaro, and M. Fermaud. 2011. Autofluorescence of grape berries following Botrytis cinerea infection. Int. J. Remote Sensing 32:3835-3849.

Ben Maachia, S., R. Errakhi, M. Chérif, P. Nandal, T. Mohapatra, and P. Bernard. 2015. Biological control of the grapevine diseases 'grey mold' and 'powdery mildew' by Bacillus B27 and B29 strains. Indian J. Exp. Biol. 53:109-115.

Beresford, R.M., K.J. Evans, P.N. Wood, and D.C. Mundy. 2006. Disease assessment and epidemic monitoring methodology for bunch rot (Botrytis cinerea) in grapevines. N.Z. Plant Prot. 59:355360.

Bettiga, L.J., W. D. Gubler, J.J. Marois, and A.M. Bledsoe. 1986. Integrated control of Botrytis bunch rot of grape. Calif. Agr. March-April p.9-11.

Blaich, R., U. Stein, and R. Wind. 1984. Perforationen in der Cuticula von Weinbeeren als morphologischer Faktor der Botrytisresistenz. Vitis 23:242-256.

Brent, K. J. and D.W. Hollomon. 2007a. Fungicide resistance in crop pathogens: How can it be managed? Fungicide Resistance Action Committee (FRAC) Monogr. No. 1, Brussels, Belgium. 56 pp.

Brent, K. J. and D.W. Hollomon. 2007b. Fungicide resistance: The Assessment of risk. Fungicide Resistance Action Committee (FRAC) Monogr. No. 2, Brussels, Belgium. 51 pp. 
Broome, J.C., J.T. English, J.J. Marois, B.A. Latorre, and J.C. Avilés. 1995. Development of an infection model for Botrytis bunch rot of grapes based on wetness duration and temperature. Phytopathology 85:97-102.

Büttner P., F. Koch, K. Voigt, T. Quidde, S. Risch, R. Blaich, B. Bruckner, and P. Tudzynski. 1994. Variations in ploidy among isolates of Botrytis cinerea: implications for genetic and molecular analyses. Curr. Genet. 25:445-450.

Calvo-Garrido, C., P.G.A. Elmer, I. Viñas, J.Usall, E.Bartra, and N- Teixidó. 2013. Biological control of botrytis bunch rot in organic wine grapes with the yeast antagonist Candida sake CPA-1. Plant Pathol. 62:510-519.

Calvo-Garrido, C., J. Usall, I. Viñas, P.A.G. Elmer, E. Cases, and N. Teixid. 2014a. Potential secondary inoculum sources of Botrytis cinerea and their influence on bunch rot development in dry Mediterranean climate vineyards. Pest. Manag. Sci . 70:922-930.

Calvo-Garrido, C., I. Viñas, P.A.G. Elmer, J. Usall, and N. Teixidó. 2014b. Suppression of Botrytis cinerea on necrotic grapevine tissues by earlyseason applications of natural products and biological control agents. Pest. Manag. Sci. 70:595602.

Cantu, D., L.C. Greve, J.M. Labavitch, and A.L.T. Powell. 2009. Characterization of the cell wall of the ubiquitous plant pathogen Botrytis cinerea. Mycol. Res. 113: 1396-1403.

Carisse, O., D.M. Tremblay, and A. Lefebvre. 2014. Comparison of Botrytis cinerea airborne inoculum progress curves from raspberry, strawberry and grape plantings. Plant Pathol. 63:983-993.

Carreño, I., and M. Alvarez. 1990. Determinación de razas resistentes de Botrytis cinerea de vides a fungicidas dicarboximidas. Chil. J. Agr. Res. 50:298-303.

Castro, M., K. Kramer, L. Valdivia, S. Ortiz, and A. Castillo. 2003. A double-stranded RNA mycovirus confers hypovirulence-associated traits to Botrytis cinerea. FEMS Microbiol. Lett. 228:8791.

Chardonnet, C., and B. Donèche, 1995. Relation between calcium content and resistance to enzy- matic digestion of the skin during grape ripening. Vitis 34:95-98.

Chervin, C., D. Lavigne, and P. Westercamp. 2009. Reduction of gray mold development in table grapes by preharvest sprays with ethanol and calcium chloride. Postharv. Biol. Technol. 54:115117.

Choquer, M., M. Boccara, and A. Vidal-Cros. 2003. A semi-quantitative RT-PCR method to readily compare expression levels within Botrytis cinerea multigenic families in vitro and in planta. Curr. Genet. 43: 303-309.

Ciliberti, N., M. Fermaud, L. Languasco, and V. Rossi. 2015a. Influence of fungal strain, temperature, and wetness duration on infection of grapevine inflorescences and young berry clusters by Botrytis cinerea. Phytopathology 105:325-333.

Ciliberti, N., M. Fermaud, J. Roudet, and V. Rossi, 2015b. Environmental conditions affect Botrytis cinerea infection of mature grape berries more than the strain or transposon genotype. Phytopathology 105:1090-1096.

Coertze, S., and G. Holz. 1999. Surface colonization, penetration, and lesion formation on grapes inoculated fresh or after cold storage with single airborne conidia of Botrytis cinerea. Plant Dis. 83:917-924.

Coertze, S., and G. Holz. 2002. Epidemiology of Botrytis cinerea on grape: wound infection by dry, airborne conidia. S. Afr. J. Enol. Vitic. 23:72-77.

Coley-Smith, J.R., K. Verhoeff, and W.R. Jarvis. 1980. The Biology of Botrytis. London: Academic Press.318 pp.

Comménil, P., L. Brunet, and J.-C. Audran. 1997. The development of the grape berry cuticule in relation to susceptibility to bunch rot disease. J. Exp. Bot. 48:1599-1607.

Corbaz, R. 1972. Etudes des spores fongiques captées dans l'air. J. Phytopathol. 74: 318-328.

Cotoras, M., and E. Silva. 2005. Differences in the initial events of infection of Botrytis cinerea strains isolated from tomato and grape. Mycologia 97:485-492.

De Bem, B.P., A. Bogo, S. Everhart, R.T. Casa, M.J. Goncalves, J.L. Marcon, and I.C. da Cunha. 
2015. Effect of Y-trellis and vertical shoot positioning training systems on downy mildew and botrytis bunch rot of grape in highlands of southern Brazil. Sci. Hortic. 185:162-166.

De Kock, P.I., and G. Holz. 1994. Application of fungicides against postharvest Botrytis bunch rot of table grapes in the Western Cape. S. Afr. J. Enol. Vitic. 15:33-40.

De Miccolis Angelini, R.M., T. Milicevic, T. Natale, P. Lepore, A. De Guido, M.A. Pollastro, B. Cvjetkovic, and F. Faretra. 2003. Botryotinia fuckeliana isolates carrying different transposons show differential response to fungicide and localization on host plant. J. Plant Pathol. 85:288-289.

De Miccolis Angelini, R.M., C. Rotolo, M. Masiello, D. Gerin, S. Pollastro, and F. Faretra. 2014. Occurrence of fungicide resistance in populations of Botryotinia fuckeliana (Botrytis cinerea) on table grape and strawberry in southern Italy. Pest. Manag. Sci . 70:1785-1796.

Dewey, F., and D. Yohalem . 2004. Detection, quantification and immunolocalisation of Botrytis species. Pages 181-194. In: Y. Elad, B. Williamson, P. Tudzynski, and N. Delen (eds.). Botrytis: Biology, Pathology and Control. Kluwer Academic Publishers. Dordrecht. The Netherlands. 428 pp.

Deytieux-Belleau, C., L. Geny, J. Roudet, V. Mayet, B. Doneche, and M. Fermaud. 2009. Grape berry skin features related to ontogenic resistance to Botrytis cinerea. Eur. J. Plant Pathol.125:551-563.

Diaz, M.R., I. Iglesias, and V. Jato. 1998. Seasonal variation of airborne fungal spore concentrations in a vineyard of North-West Spain. Aerobiologia 14:221-227.

Diguta, C.F., S. Rousseaux, S. Weidmann, N. Bretin, B.Vincent, M. Guilloux-Benatier, and H. Alexandre. 2010. Development of a qPCR assay for specific quantification of Botrytis cinerea on grapes. FEMS Microbiol. Lett. 313:81-87.

Diolez A., F. Marches, D. Fortini, and Y. Brygoo. 1995. Boty, a long-terminal-repeat retroelement in the phytopathogenic fungus Botrytis cinerea. Appl. Environ. Microbiol. 61:103-108.

Doss, R.P., S.W. Potter, A.H. Soeldner, J.K. Christian, L.E. Fukunaga. 1995. Adhesion of germ- lings of Botrytis cinerea. Appl. Env. Microbiol. 61:260-265.

Droby, S., M. Wisniewski, D. Macarisin, and C. Wilson. 2009. Twenty years of postharvest biocontrol research: Is it time for a new paradigm? Postharv. Biol. Technol. 52:137-145.

Duncan, R.A., J.J. Stapleton, and G.M. Leavitt. 1995. Population dynamics of epiphytic microflora and occurrence of bunch rot of wine grapes as influenced by leaf removal. Plant Pathol. 44:956-965.

Edder, P., D. Ortelli, O. Viret, E. Cognard, A. De Montmollin, and O. Zali. 2009. Control strategies against grey mould (Botrytis cinerea Pers.: Fr) and corresponding fungicide residues in grapes and wines. Food Addit. Contam. 26:719-725.

Elad, Y., and K. Evensen. 1995. Physiological aspects of resistance to Botrytis cinerea. Phytopathology 85:637-642.

Elad, Y., and A. Stewart. 2004. Microbial Control of Botrytis spp. Pages 223-241. In: Y. Elad, B. Williamson, P. Tudzynski, and N. Delen (eds.). Botrytis: Biology, Pathology and Control. Kluwer Academic Publishers. Dordrecht. The Netherlands. 428 pp.

Elad, Y., B. Williamson, P. Tudzynski, and N. Delen. 2004. Botrytis: Biology, Pathology and Control. Dordrecht, The Netherlands: Kluwer Academic Press. 403 pp.

El Ghaouth, A., C.L. Wilson, and M. Wisniewski. 2003. Control of postharvest decay of apple fruit with Candida saitoana and induction of defense responses. Phytopathology 93:344-348.

Elmer, P.A.G., and T.J. Michailides. 2004. Epidemiology of Botrytis cinerea in orchard and vine crops. Pages 243-272. In: Y. Elad, B. Williamson, P. Tudzynski, and N. Delen (eds.). Botrytis: Biology, Pathology and Control. Kluwer Academic Publishers. Dordrecht. The Netherlands. 428 pp.

Elmer, P.A.G., and T. Reglinski. 2006. Biosuppression of Botrytis cinerea in grapes. Plant Path. 55:155-177.

English, J.Y., A.M. Bledsoe, and J.J. Marois. 1990. Influence of leaf removal from the fruit cluster zone on the components of evaporative potential within grapevine canopies. Agic. Ecosyst. Environ. 31:49-61. 
English, J.T., C.S. Thomas, J.J. Marois, and W.D. Gubler. 1989. Microclimates of grapevine canopies associated with leaf removal and control of Botrytis bunch rot. Phytopathology 79:395-401.

English, J.T., M.L. Kaps, J.F. Moore, J. Hill, and M. Nakova. 1993. Leaf removal for control of Botrytis bunch rot of wine grapes in the midweatern United States. Plant Dis. 77:1224-1227.

Esterio, M., J. Auger, A. Droguett, S. Flanagan, F. Campos. 2000. Efficacy of Bacillus subtilis (Ehrenberg), Cohn., QST-713 Strain (Serenade ${ }^{\mathrm{TM}}$ ), on Botrytis cinerea control in table grape (Vitis vinifera $\mathrm{L}$. cv Thompson Seedless). In: Proceedings of the XII International Botrytis Symposium, Reims, France. Europol Agro, Abstract L27.

Esterio, M., J. Auger, C. Ramos, and H. García. 2007. First report of fenhexamid resistant isolates of Botrytis cinerea on grapevine in Chile. Plant Dis. 91:768-768.

Esterio, M., G. Muñoz, C. Ramos, G. Cofré, R. Estévez, A. Salinas, and J. Auger. 2011. Characterization of Botrytis cinerea isolates present in Thompson Seedless table grapes in the Central Valley of Chile. Plant Dis. 95:683-690.

Esterio, M., M.J. Araneda, A. Roman, L. Pizarro, C. Copier, and J. Auger. 2015. First report of boscalid resistant Botrytis cinerea isolates carrying the mutations H272R, H272Y, P225L and P225H from table grape in Chile. Plant Dis. 99:891-801.

Evans, K.J. 2010. Integrated management of Botrytis bunch rot. Fact Sheet. Tasmanian Institute of Agricultural Science, University of Tasmania, Australia. www.gwrdc.com.au (Accessed: March 2015).

Farace, G., O. Fernandez, L. Jacquens, F. Coutle, F. Krier, P. Jacques, C. Clemant, E.A. Barka, C. Jacquard, S. Dorey. 2015. Cyclic lipopeptides from Bacillus subtilis activate distinct patterns of defence responses in grapevines. Mol. Plant Pathol. 16:177-187.

Faretra, F., and E. Antonacci. 1987. Production of apothecia of Botryotinia fuckeliana (de Bary) Whetz. under controlled environmental conditions. Phytopathol. Mediterr. 26:29-35.
Faretra, F. and B.A. Latorre. 2007. Determinación de razas sexualmente compatibles de Botrytis cinerea en Chile. Simiente (Chile) 67:68-95 (Abstract).

Faretra F., E. Antonacci, and S. Pollastro. 1988. Sexual behaviour and mating system of Botryotinia fuckeliana, teleomorph of Botrytis cinerea. J. Gen. Microbiol. 134:2543-2550.

Ferrada, E. E., B. A. Latorre, G.A. Diaz, and J.P. Zoffoli. 2014. Identification of Botrytis spp. causing blossom blight in Japanese plums and nectarines in Chile. Phytopathology 104:S3.40.

Fermaud, M., and Le Menn, R. 1989. Association of Botrytis cinerea with grape berry moth larvae. Phytopathology 79:651-656.

Fernández-Baldo, M.A., J.G. Fernández, S.V. Pereira, G.A. Messina, E. Salinas, J. Raba, and M.I. Sanz Ferramola. 2011. Development of an indirect competitive enzyme linked immunosorbent assay applied to the Botrytis cinerea quantification in tissues of postharvest fruits. BMC Microbiol. 11:220-228.

Fernández-González, M., F.J. Rodríguez-Rajo, V. Jato, M.J. Aira, H. Ribeiro, M. Oliveira, and I. Abreu. 2012. Forecasting ARIMA models for atmospheric vineyard pathogens in Galicia and Northern Portugal: Botrytis cinerea spores. Ann. Agric. Environ. Med. 19:255-262.

Ferree, D.C., M.A. Ellis, S.J. McArtney, M.V. Brown, and D.M. Scurlock. 2003. Comparison of fungicide, leaf removal and gibberellic acid on development of grape cluster and Botrytis bunch rot of 'Vignoles' and 'Pinot Gris'. Small Fruits Rev. 2(4):3-18.

Fournier, E., T. Giraud, C. Albertini, and Y. Brygoo. 2005. Partition of the Botrytis cinerea complex in France using multiple gene genealogies. Mycologia 97:1251-1267.

Fournier, E., C. Levis, D. Fortini, T. Giraud, P. Leroux, and Y. Brygoo. 2003. Characterization of $\mathrm{Bc}-\mathrm{hch}$, the Botrytis cinerea homolog of the Neurospora crassa het-c vegetative incompatibly locus, and its use as population marker. Mycologia 95:251-261.

Flamini, R., F. Mattivi, M. De Rosso, P. Arapitsas, and L. Bavaresco. 2013. Advanced knowledge of 
three important classes of grape phenolics: anthocyanins, stilbenes and flavonols. Int. J. Mol. Sci. 14:19651-19669.

FRAC. 2015. FRAC Code List. 2015: Fungicides sorted by mode of action (including FRAC Code numbering). Fungicide Resistance Action Committee. USA. www.frac.info. (Accessed March 2015).

Franck, J., B.A. Latorre, R. Torres, and J.P. Zoffoli. 2005. The effect of preharvest fungicide and postharvest sulfur dioxide use on postharvest decay of table grapes caused by Penicillium expansum. Postharv. Biol. Technol. 37:20-30.

Giraud, T., D. Fortini, C. Levis, P. Leroux, and Y. Brygoo. 1997. RFLP markers show genetic recombination in Botryotinia fuckeliana (Botrytis cinerea) and transposable elements reveal two sympatric species. Mol. Biol. Evol. 14:1177-1185.

Giraud, T., D. Fortini, C. Levis, C. Lamarque, P. Leroux, K. LoBuglio, and Y. Brygoo. 1999. Two sibling species of the Botrytis cinerea complex, transposa and vacuma, are found in sympatry on numerous host plants. Phytopathology 89:967973.

Goetz, G., A. Fkyerat, N. Metais, M. Kunhz, R. Tabacchi, R. Pezet, and V. Pont. 1999. Resistance factors to grey mould in grape berries: identification of some phenolics inhibitors of Botrytis cinerea stilbene oxidase. Phytochemistry 52:759-767.

Gindro, K., N. Lecoultre, L. Molino, J.-P. de Joffrey, S. Schnee, F. Voinesco, V. Alonso-Villaverde, O. Viret, and P.-H. Dubuis. 2014. Development of rapid direct PCR assays to identify downy and powdery mildew and grey mould in Vitis vinifera tissues. J. Int. Sci. Vigne Vin 48:261-268.

González-Domínguez, E., T. Caffi, N. Ciliberti, V. Rossi. 2015. A mechanistic model of Botrytis cinerea on grapevines that includes weather, vine growth stage, and the main infection pathways. PLoS ONE 10(10): e0140444.

Gubler, W.D., L.J. Bettiga, and D. Heil. 1991. Comparisons of hand and machine leaf removal for the control of Botrytis bunch rot. Am. J. Enol. Vitic. 42:233-236.

Gubler, W.D., J.J. Marois, A.M. Bledsoe, and L.J. Bettinga. 1987. Control of Botrytis bunch rot of grape with canopy management. Plant Dis. 71:599-561.

Harman, G.E., B.A. Latorre, E. Agosín, R. San Martín, D.G. Riegel, P.A. Nielsen, A. Tronsmo, and R.C. Pearson. 1996. Biological and integrated control of Botrytis bunch rot of grape using Trichoderma spp. Biol. Control 7:259-266.

Harvey, J.M. 1955. A method of forecasting decay in California storage grapes. Phytopathology 45:229-232.

Hed, B., H.K. Ngugi, and J.W. Travis. 2009. Relationship between cluster compactness and bunch rot in Vignoles grapes. Plant Dis. 93:1195-1201.

Hed, B., H.K. Ngugi, and J.W. Travis. 2011. Use of gibberellic acid for management of bunch rot on Chardonnay and Vignoles grape. Plant Dis.95:269-278

Hed, B., H.K. Ngugi, and J.W. Travis. 2015. Shortand long-term effects of leaf removal and gibberellin on Chardonnay grapes in the Lake Erie Region of Pennsylvania. Am. J. Enol. Vitic. 66:22-29.

Herzog, K., R. Wind, and R. Töpfer. 2015. Impedance of the grape berry cuticle as a novel phenotypic trait to estimate resistance to Botrytis cinerea. Sensors 15:12498-12512.

Hill, G., F. Stellwaag-Kittler, G. Huth, and E. Schlösser. 1981. Resistance of grapes in different developmental stages to Botrytis cinerea. J. Phytopathol. 102:328-338.

Hill, G.N., R.M. Beresford, and K.J. Evans. 2010. Tools for accurate assessment of botrytis bunch rot (Botrytis cinerea) on wine grapes. N. Z. Plant Prot. 63:174-181.

Hill, G.N., K.J. Evans, and R.M. Beresford. 2014. Use of nitrate non-utilizing (nit) mutants to determine phenological stages at which Botrytis cinerea infects wine grapes causing botrytis bunch rot. Plant Pathol. 63:1316-1313.

Holz, G., M. Gutschow, S. Coertze, and F.J. Calitz. 2003. Occurrence of Botrytis cinerea and subsequent disease suppression at different positions on leaves and bunches of grape. Plant Dis. 87:351-358.

Holz, G., S. Coertze, and B. Williamson. 2004. The ecology of Botrytis on plant surfaces. pages 9-27. 
In: Y. Elad, B. Williamson, P. Tudzynski, and N. Delen (eds.). Botrytis: Biology, Pathology and Control. Kluwer Academic Publishers. Dordrecht. The Netherlands. 428 pp.

Howitt, R.L.J., R.E. Beever, M.N. Pearson, and R.L.S. Forster. 1995. Presence of double-stranded RNA and virus-like particles in Botrytis cinerea. Mycol. Res. 99:1472-1478.

Jacometti, M.A., S.D. Wratten, and M. Walter. 2010. Review: Alternatives to synthetic fungicides for Botrytis cinerea management in vineyards. Aust. J. Grape Wine Res.16:154-172.

Jeandet, P., R. Bessis, and B. Gaugheron. 1991. The production of resveratrol $(3,5,4$ '-trihydroxystilbene) by grape berries in different developmental stages. Am. J. Enol. Vitic. 42:41-46.

Jermini, M., G. Jelmini, and C. Gessler. 1986. Control of Botrytis cinerea on Merlot grapevine in Ticino. Role of latent infections. Rev. Suisse Vitic. Arboric. Hortic.18:161-166.

Johnston, P.R., K. Hoksbergen, D. Park, and R.E. Beever. 2014. Genetic diversity of Botrytis in New Zealand vineyards and the significance of its seasonal and regional variation. Plant Pathology 63:888-898.

Kars, I., and J.A.L. van Kan. 2004. Extracellular enzymes and metabolites involved in pathogenesis of Botrytis. Pages 98-118. In: Y. Elad, B. Williamson, P. Tudzynski, and N. Delen (eds.). Botrytis: Biology, Pathology and Control. Kluwer Academic Publishers. Dordrecht. The Netherlands. $428 \mathrm{pp}$.

Keller, M., M. Kummer, and M.C. Vasconcelos. 2001. Reproductive growth of grapevines in response to nitrogen supply and rootstock. Aust. J. Grape Wine Res. 7: 12-18

Keller, M., S.Y. Rogiers, and H.R. Schultz. 2003a. Nitrogen and ultraviolet radiation modify grapevines' susceptibility to powdery mildew. Vitis 42:87-94.

Keller, M., O. Viret, and M. Cole. 2003b. Botrytis cinerea infection in grape flowers: Defence reaction, latency and disease expression. Phytopathology 93:316-322.

Kerssies, A. 1990. A selective medium for Botrytis cinerea to be used in a spore-trap. Neth. J. Plant Pathol. 96:247-250.
Kim, K.S., R.M. Beresford, and W.R. Henshall. 2007. Prediction of disease risk using site-specific estimates of weather variables. N.Z. Plant Prot. 60:128-132.

Komárek, M., E. Cadková, V. Chrastný, F. Bordas, and J.C. Bollinger. 2010. Contamination of vineyard soils with fungicides: a review of environmental and toxicological aspects. Environ. Int. 36:138-151.

Latorre, B.A. 2007. Gray mold (Botrytis cinerea), a limiting factor for table grapes production in Chile. Fitopatología 42:9-20.

Latorre, B.A. 2013. Control biológico de Botrytis cinerea en especies frutales en Chile. Pages 3544, In: J.R. Montealegre, and L.M. Perez (eds.). Control Biológico de Enfermedades de las Plantas en Chile. Departamento de Sanidad Vegetal, Facultad de Ciencias Agronómicas, Universidad de Chile. Santiago, Chile. 147 pp.

Latorre, B.A. and M.E. Rioja. 2002. Efecto de la temperatura y de la humedad relativa sobre la germinación de conidias de Botrytis cinerea. Cien. Inv. Agr. 29:67-72.

Latorre, B.A., and R. Torres. 2012. Prevalence of isolates of Botrytis cinerea resistant to multiple fungicides in Chilean vineyards. Crop Prot. 40:49-52.

Latorre, B.A. and G. Vásquez. 1996. Situación de Botrytis cinerea latente en uva de mesa de la zona Central. Aconex (Chile) 52:23-28.

Latorre, B.A., E.X. Briceño, and R. Torres. 2011. Increase in Cladosporium spp. populations and rot of wine grapes associated with leaf removal. Crop Prot. 30:52-56.

Latorre, B.A., M.E. Rioja, and C. Lillo. 2001. Eficacia de los tratamientos fungicidas para el control de Botrytis cinerea de la vid en función de la época de aplicación. Cien. Inv. Agr. 28:61-66.

Latorre, B.A., M.E. Rioja, and C. Lillo. 2002. Efecto de la temperatura en el desarrollo de la infección producida por Botrytis cinerea en flores y bayas de uva de mesa. Cien. Inv. Agr. 29:145-151.

Latorre, B.A., I. Spadaro, and M.E. Rioja. 2002. Occurrence of resistant strains of Botrytis cinerea to anilinopyrimidine fungicides in table grapes in Chile. Crop Prot. 21:957-961. 
Latorre, B.A., E. Agosin, R. San Martín, and G.S. Vásquez. 1997. Effectiveness of conidia of Trichoderma harzianum produced by liquid fermentation against Botrytis bunch rot of table grape in Chile. Crop Prot. 16:209-214.

Latorre, B.A., V. Flores, A.M. Sara, and A. Roco. 1994. Dicarboximide-resistant isolates of Botrytis cinerea from table grape in Chile: survey and characterization. Plant Dis. 78:990-994.

Latorre, B.A., S. Rojas, G.A. Díaz, and H. Chuaqui. 2012. Germicidal effect of UV light on epiphytic fungi isolated from blueberry. Cien. Inv. Agr. 39:473-480.

Leroch, M., M. Kretschmer, and M. Hahn. 2011. Fungicide resistance phenotypes of Botrytis cinerea isolates from commercial vineyards in south west Germany. J. Phytopathol. 159:63-65.

Leroux, P. 2004. Chemical control of Botrytis and its resistance to chemical fungicides. Pages $195-$ 222. In: Y. Elad, B. Williamson, P. Tudzynski, and N. Delen (eds.). Botrytis: Biology, Pathology and Control. Kluwer Academic Publishers. Dordrecht. The Netherlands. 428 pp.

Leroux, P., R. Fritz, D. Debieu, C. Albertini, C. Lanen, J. Bach, M. Gredt, and F. Chapeland. 2002. Mechanisms of resistance to fungicide in field strains of Botrytis cinerea. Pest Mang. Sci. 58:876-888

Levis, C., D. Fortini, and Y. Brygoo. 1997. Flipper, a mobile Fot1-like transposable element in Botrytis cinerea. Mol. Gen. Genet. 254:674-680.

Leyronas, C., and P.C. Nicot. 2013. Monitoring viable airborne inoculum of Botrytis cinerea in the South-East of France over 3 years: relation with climatic parameters and the origin of air masses. Aerobiologia 29:291-299.

Lorenzini, M., and G. Zapparoli. 2014. An isolate morphological and phylogenetically distinct from Botrytis cinerea obtained from withered grapes possible represents a new species of Botrytis. Plant Pathol.63:1326-1335.

Ma, Z., and T.J. Michailides. 2005. Genetic structure of Botrytis cinerea populations from different host plants in California. Plant Dis. 89:1083-1089.

Madden, L.V. 1980. Quantification of disease progression. Prot. Ecol. 2:159-176.
Marois, J.J., J.K. Nelson, J.C. Morrison, L.S. Lile, and A.M. Bledsoe. 1986. The influence of berry contact within grape clusters on the development of Botrytis cinerea and epicuticular wax. Am. J. Enol.Vitic. 37:293-296.

Marois, J.J., A.M. Bledsoe, R.M. Bostock, and W.D. Gubler. 1987. Effect of spray adjuvants on development of Botrytis cinerea on Vitis vinifera berries. Phytopathology 77:1148-1152.

Martinez, J.P., D. Blancard, P. Locomte, and C. Levis. 2003. Phenotypic differences between vacuma and transpose subpopulations of Botrytis cinerea. Eur. J. Plant Pathol.109:479-488.

McClellan W.D., and W.B. Hewitt. 1973. Early Botrytis rot of grapes: Time of infection and latency of Botrytis cinerea Pers. in Vitis vinifera L. Phytopathology 63:1151-1157.

Miceli, A., A. Ippolito, V. Linsalata, and F. Nigro. 1999. Effect of preharvest calcium treatment on decay and biochemical changes of table grape during storage. Phytopathol. Mediterr. 38:47-53.

Mlikota Gabler F.M., J.L. Smilanick, M. Mansour, D.W. Ramming, and B.E. Mackey. 2003. Correlations of morphological, anatomical, and chemical features of grape berries with resistance to Botrytis cinerea. Phytopathology 93:1263-1273.

Molitor, D., M. Rothmeier, M. Behr, S. Fischer, L. Hoffmann, and D. Evers. 2011. Crop cultural and chemical methods to control grey mould on grapes. Vitis 50:81-87.

Montealegre, J.R., and L.M. Pérez. 2014. Control biológico de enfermedades de plantas en Chile. In: Pages 157-168, W. Bettiol, M.C. Rivera, P. Mondino, J.R. Montealegre, Y. C. Colmenárez (eds.). Control Biológico de Enfermedades de Plantas en América Latina y el Caribe. Facultad de Agronomía. Montevideo, Uruguay. 404 pp.

Mujica, F., and C. Vergara. 1980. Flora Fungosa Chilena. Second ed. Ciencias Agrícolas 5. Universidad de Chile, Santiago, Chile. 308 pp.

Mundy, D.C. 2008. A review of the direct and indirect effects of nitrogen on botrytis bunch rot in wine grapes. N.Z. Plant Prot. 61:306-310.

Mundy, D.C., and R.M. Beresford. 2007. Susceptibility of grapes to Botrytis cinerea in relation 
to berry nitrogen and sugar concentration. N.Z. Plant Prot. 60:123-127.

Mundy, D.C., R.H. Agnew, and P.N. Wood. 2012. Grape tendrils as an inoculum source of Botrytis cinerea in vineyards - a review. N.Z. Plant Prot. 65:218-227.

Muñoz, G., P. Hinrichsen, and M. Alvarez. 1999. Variabilidad genética de cepas de Botrytis cinerea provenientes de vid y tomate con resistencia a dicarboximidas. Chil. J. Agr. Res. 59:3-12.

Muñoz, G., P. Hinrichsen, Y. Brygoo, and T. Giraud. 2002. Genetic characterization of Botrytis cinerea populations in Chile. Mycol. Res. 106:594601.

Myresiotis, C.K., G.S. Karaoglanidia, and K. Tzavella-Klonari. 2007. Resistance of Botrytis cinerea isolates from vegetable crops to anilinopyrimidine, phenylpyrrole, hydroxyanilide, benzimidazole, and dicarboximide fungicides. Plant Dis. 91:407-413.

Nair, N.G., and R.N. Allen.1993. Infection of grape flowers and berries by Botrytis cinerea as a function of time and temperature. Mycol. Res. 97:1012-1014.

Nair, N.G., and A. Nadtotchei. 1987. Sclerotia of Botrytis as a source of primary inoculum for bunch rot of grapes in New South Wales. Aust. J. Phytopathol. 119:42-51.

Nair, N.G., and F.E. Parker. 1985. Midseason bunch rot of grapes: an unusual disease phenomenon in the Hunter Valley. Plant Pathol. 34:302-305.

Nair, N.G., R.W. Emmett, and F.E. Parker. 1988. Some factors predisposing grape berries to infection by Botrytis cinerea. N.Z. J. Exp. Agric. 16:257-263.

Nair, N.G., S. Guilbaud-Oulton, I. Barchia, and R. Emmett. 1995. Significance of carryover inoculum, flower infection and latency on the incidence of Botrytis cinerea in berries of grapevines at harvest in New South Wales. Aust. J. Exp. Agric. 35:1177-1180.

Nally, M.C., V.M. Pesce, Y.P. Maturano, C.J. Muñoz, M. Combina, M.E. Toro, L.I. Castellanos de Figueroa, and F. Vazquez. 2012. Biocontrol of Botrytis cinerea in table grapes by non-pathogenic indigenous Saccharomyces cerevisiae yeasts isolated from viticultural environments in Argentina. Postharv. Biol. Technol. 64:40-48.

Nelson, K.E. 1951. Factors influencing the infection of table grapes by Botrytis cinerea. Phytopathology 41:859-864.

Nigro, F., L. Schena, A. Ligorio, I. Pentimone, A. Ippolito, and M.G. Salerno. 2006. Control of table grape storage rots by pre-harvest applications of salts. Postharv. Biol. Technol. 42:142-149.

Obanor, F., K. Williamson, D. Mundy, P. Wood, and M. Walter. 2004. Optimisation of PTA-ELISA detection and quantification of Botrytis cinerea infections in grapes. N.Z. Plant Prot.57:130-137.

Parafati, L., A. Vitale, C. Restuccia, and G. Cirvilleri. 2015. Biocontrol ability and action mechanism of food-isolated yeast strains against Botrytis cinerea causing post-harvest bunch rot of table grape. Food Microbiol. 47:85-92.

Pavan, F., G. Bigot, E. Cargnus, and P. Zandigiacomo. 2014. Influence of the carpophagous generations of the European grapevine moth Lobesia botrana on grape bunch rots. Phytoparasitica 42:61-69.

Pearson, R.C., and D.G. Riegel. 1983. Control of Botrytis bunch rot of ripening grapes: Timing applications of the dicarboximide fungicides. Am. J. Enol. Vitic. 34:167-172.

Percival, D.C., J.A. Sullivan, and K.H. Fisher. 1993. Effect of cluster exposure, berry contact and cultivar on cuticular membrane formation and occurrence of bunch rot (Botrytis cinerea Pers.: Fr.) with three Vitis vinifera L. cultivars. Vitis 32:87-97.

Percival, D.C., K.H. Fisher, and. J.A. Sullivan. 1994. Use of fruit zone leaf removal with Vitis vinifera L. cv. Riesling grapevines. II. Effect on fruit composition, yield, and occurrence of bunch rot (Botrytis cinerea Pers.:Fr.). Am. J. Enol. Vitic. 45:133-140.

Petit, A.N., N. Vaillant-Gaveau, A.S. Walker, P. Leroux, F. Baillieul, M.L. Panon, C. Clément, and F. Fontaine. 2010. Determinants of fenhexamid effectiveness against grey mould on grapevine: respective role of spray timing, fungicide resistance and plant defences. Crop Prot. 29:11621167. 
Pezet, R., and V. Pont. 1986. Infection florale et latence de Botrytis cinerea dans les grappes de Vitis vinifera (var. Gamay). Rev. Suisse Vitic. Arboric. Hortic. 18:317-322.

Pezet, R., O. Viret, C. Perret, and R. Tabacchi. 2003. Latency of Botrytis cinerea Prs.:Fr. and biochemical studies during growth and ripening of two grape berry cultivars, respectively susceptible and resistant to grey mould. J. Phytopathol. 151:208-214.

Phillips, P.A., J.H. Foott, and L. Righetti. 1990. Grape pruning methods can affect Botrytis bunch rot. Calif. Agr. 44:9-10.

Piqueras, C.M., D. Herrera, and B.A. Latorre. 2014. First Report of high boscalid resistance in Botrytis cinerea associated with H272L mutation in grapevine in Chile. Plant Dis. 98:1441-1441.

Pollastro, S., F. Faretra, V. Di Canio, and A. De Guido. 1996. Characterization and genetic analysis of field isolates of Botryotinia fuckeliana (Botrytis cinerea) resistant to dichlofluanid. Eur. J. Plant Pathol. 102:607-613.

Poni, S., L. Casalini, F. Bernizzoni, S. Civardi, and C. Intrieri. 2006. Effects of early defoliation on shoot photosynthesis, yield components, and grape composition. Am. J. Enol. Vitic. 57:397-407.

Prajitna, A., I.E. Damil, T.E. Steiner, D.C. Feree, J.C. Scheerens, and S.J. Schwartz. 2007. Influence of cluster thinning on phenolic composition, resveratrol, and antioxidant capacity in Chambourcin Wine. Am. J. Enol. Vitic. 58:346-350.

Prusky, D., and A. Lichter. 2007. Activation of quiescent infections by postharvest pathogens during transition from the biotrophic to the necrotrophic stage. FEMS Microbiol. Lett. 268:1-8.

Reglinski, T., P.A.G. Elmer, J.T. Taylor, F.J. Parry, R. Marsden, and P.N. Wood. 2005. Suppression of Botrytis bunch rot in chardonnay grapevines by induction of host resistance and fungal antagonism. Australas. Plant Pathol. 34:481-488.

Ricker, R., J.J. Marois, R. Dlott, and J. Morrison. 1991. Immunodetection and quantification of Botrytis cinerea on harvested wine grapes. Phytopathology 81:404-411.

Rodríguez-Rajo, F.J., V. Jato, M. FernándezGonzález, and M.J. Aira. 2010. The use of aero- biological methods for forecasting Botrytis spore concentrations in a vineyard. Grana 49:56-65.

Rodríguez-Rajo, F.J., M.C. Seijo-Coello, and M.V. Jato-Rodríguez. 2002. Estudio de los niveles de los principales fitopatógenos para la optimización de cosechas de Vitis vinifera en Valdeorras, Ourense (1998). Bot. Complutensis 26:121135.

Romanazi, G., A. Lichter, F.M. Gabler, and J.L. Smilanick. 2012. Recent advances on the use of natural and safe alternatives to conventional methods to control postharvest gray mold of table grapes. Postharv. Biol. Technol. 63:141-147.

Rotem, J., and H.J. Aust. 1991. The effect of ultraviolet and solar radiation and temperature on survival of fungal propagules. J. Phytopathol. 133:76-84.

Rubio, J., C. Montes, A. Castro, C. Alvarez, B. Olmedo, M. Muñoz, E. Tapia, F. Reyes, M. Ortega, E. Sánchez, M. Miccono, L. Dalla Costa, L. Martinelli, M. Malnoy, H. Prieto. 2015. Genetically engineered Thompson Seedless grapevine plants designed for fungal tolerance: selection and characterization of the best performing individuals in a field trial. Transgenic Res. 24:43-60.

Ruiz, E., and H.P. Ruffner. 2002. Immunodetection of Botrytis-specific invertase in infected grapes. J. Phytopathol. 150:76-85.

Sanders, D., C. Brownlee, and J.F. Harper. 1999. Communicating with calcium. Plant Cell 11:691-706.

Sanzani, S.M., L. Schena, V. De Cicco, and A. Ippolito. 2012. Early detection of Botrytis cinerea latent infections as a tool to improve postharvest quality of table grapes. Postharv. Biol. Technol. 68:64-71.

Savage S.D., and M.A. Sall M. 1982. Vineyard cultural practices may help reduce Botrytis bunch rot caused by Botrytis cinerea. Calif. Agr. 36:8-9.

Savage, S.D., and M.A. Sall. 1984. Botrytis bunch rot of grapes: Influence of trellis type and canopy microclimate. Phytopathology 74:65-70.

Serey, R.A., R. Torres, and B.A. Latorre. 2007. Preand post-infection activity of new fungicides against Botrytis cinerea and other fungi causing decay of table grapes. Cien. Inv. Agr. 34:215-224. 
Shtienberg, D. 2004. Rational management of Botrytis-induced diseases: Integration of control measures and use of warning systems. Pages 335-347. In: Y. Elad, B. Williamson, P. Tudzynski, and N. Delen (eds.). Botrytis: Biology, Pathology and Control. Kluwer Academic Publishers. Dordrecht. The Netherlands. 428 pp.

Shtienberg, D., and Y. Elad. 1997. Incorporation of weather forecasting in integrated, biologicalchemical management of Botrytis cinerea. Phytopathology 87:332-340.

Smart, R.E., J.K. Dick, I.M. Gravett, and B.M. Fisher. 1990. Canopy management to improve grape yield and wine quality: Principles and practices. S. Afr. J. Enol Vitic. 11:3-17.

Smilanick, J.L., M.F. Mansour, F. Mlikota Gabler, D.A. Margosan, and J. Hashim-Buckey. 2010. Control of postharvest gray mold of table grapes in the San Joaquin Valley of California by fungicides applied during the growing season. Plant Dis. 94:250-257.

Smithyman, R.P., G.S. Howell, and D.P. Miller. 1998. The use of competition for carbohydrates among vegetative and reproductive sinks to reduce fruit set and Botrytis bunch rot in Seyval blanc grapevines. Am. J. Enol. Vitic. 49:163-170.

Steel, C.C., L.A. Greer, S. Savocchia, and S.K. Samuelian. 2011. Effect of temperature on Botrytis cinerea, Coletotrichum acutatum, and Greeneria uvicola mixed fungal infection of Vitis vinifera grape berries. Vitis 50:69-71.

Steel, C.C., J.W. Blackman, and L.M. Schmidtke. 2013. Grapevine bunch rots: Impacts on wine composition, quality, and potential procedures for the removal of wine faults. J. Agric. Food Chem. 61:5189-5206.

Stepalska, D., and J. Wolek. 2005. Variation in fungal spore concentrations of selected taxa associated to weather conditions in Cracow, Poland, in 1997. Aerobiologia 21:43-52.

Tardaguila, J., P.R. Petrie, S. Poni, M.P. Diago, and F.M. de Toda. 2008. Effects of mechanical thinning on yield and fruit composition of Tempranillo and Grenache grapes trained to a vertical shoot-positioned canopy. Am. J. Enol. Vitic. 59:412-417.
Tenberge, K.B. 2004. Morphology and cellular organisation in Botrytis interactions with plants. Pages 67-84. In: Y. Elad, B. Williamson, P. Tudzynski, and N. Delen (eds.). Botrytis: Biology, Pathology and Control. Kluwer Academic Publishers. Dordrecht. The Netherlands. 428 pp.

Thomas, C.S., J.J. Marois, and J.T. English. 1988. The effects of wind speed, temperature, and relative humidity on development of aerial mycelium and conidia of Botrytis cinerea on grape. Phytopathology 78:260-265.

Thompson, J.R., and B.A. Latorre. 1999. Characterization of Botrytis cinerea from table grapes in Chile using RAPD-PCR. Plant Dis. 83:10901094.

Thompson, J.R., and B.A. Latorre. 1999. Characterization of fungicide resistant strains of Botrytis cinerea in Chile using the polymerase chain reaction. Fitopatología 34:140-145.

Urbasch, I. 1985. Ultrastructural studies on the microconidia of Botrytis cinerea Pers. and their phialoconidial development. J. Phytopathol. 112:229-237.

Urbasch, I. 1986. In vivo-Untersuchungen zur entstehung und funktion der chlamydosporen von Botrytis cinerea Pers. am wirt-parasit-system Fuchsia hybrida-B. cinerea. J. Phytopathol. 117:276-282.

Vail, M. E., and J.J. Marois. 1991. Grape cluster architecture and the susceptibility of berries to Botrytis cinerea. Phytopathology 81:188-191.

Valdés-Gómez, H. M. Fermaud, J. Roudet, A. Calonnec, and C. Gary. 2008. Grey mould incidence is reduced on grapevines with lower vegetative and reproductive growth. Crop Prot. 27:11741186.

van Baarlen, P., L. Legendre, and J.A.L. van Kan. 2004. Plant defence compounds against Botrytis infection. Pages 143-161. In: Y. Elad, B. Williamson, P. Tudzynski, and N. Delen (eds.). Botrytis: Biology, Pathology and Control. Kluwer Academic Publishers. Dordrecht. The Netherlands. 428 pp.

van der Vlugt-Bergmans, C.J.B., B.J. Brandwagt, J.W. van't Klooster, C.A.M. Wagemakers, and J.A.L. van Kan. 1993. Genetic variation and 
segregation of DNA polymorphisms in Botrytis cinerea. Mycol. Res. 97:1193-1200.

van Kan, J.A.L., J. Duarte, E. Dekkers, P. Dyer, and L. Khon. 2010. The Botrytis cinerea mating type loci. Page 39, Book of Abstracts 15th International Botrytis symposium, Cadiz, Spain.

van Kan, J.A.L., M.L. Shaw, and R.T. Grant-Downton. 2014. Botrytis species: relentless necrotrophic thugs or endophytes gone rogue? Mol. Plant Pathol. 15:957-961.

Vargas, M., F. Garrido, N. Zapata, and M. Tapia. 2012. Isolation and selection of epiphytic yeast for biocontrol of Botrytis cinerea Pers. on table grapes. Chil. J. Agr. Res. 72:332-337.

Vercesi, A., S.L. Toffolatti, G. Venturini, P. Campia, and S. Scagnelli. 2014. Characterization of Botrytis cinerea populations associated with treated and untreated cv. Moscato vineyards. Phytopathol. Mediterr. 53:108-123.

Vilches, S. and A. Castillo.1997. A double-stranded RNA mycovirus in Botrytis cinerea. FEMS Microbiol. Lett. 155:125-130.

Viret, O., M. Keller, V.G. Jaudzems, and F.M. Cole. 2004. Botrytis cinerea infection of grape flowers: light and electron microscopical studies of infection sites. Phytopathology 94:850-857.

Walker, A.-S., A. Gautier, J. Confais, D. Martinho, M. Viaud, P. Le Pêcheur, J. Dupont, and E. Fournier. 2011. Botrytis pseudocinerea, a new cryptic species causing gray mold in French vineyards in sympatry with Botrytis cinerea. Phytopathology 101:1433-1445.

Walter, M., K.S.H. Boyd-Wilson, J.H. Perry, P.A.G. Elmer, and C.M. Frampton. 1999. Survival of Botrytis cinerea conidia on kiwifruit. Plant Pathol. 48:823-829.
Wang, L.J., L. Ma, H.F. Xi, W. Duan, F.F. Wang, and S.H. Li. 2013. Individual and combined effects of $\mathrm{CaCl}_{2}$ and UV-C on the biosynthesis of resveratrols in grape leaves and berry skins. J. Agric. Food Chem. 61:7135-7141.

Williamson, B., B. Tudzynski, P. Tudzynski, and J.A.L. van Kan. 2007. Botrytis cinerea: the cause of grey mould disease. Mol. Plant Pathol. 8:561580.

Wolf, T.K., A. Baudoin, and N. Martinez Ochoa. 1997. Effect of floral debris removal from fruit clusters on Botrytis bunch rot of Chardonnay grapes. Vitis 36:27-33.

Zhou, Y.J., J. Zhang, X.D. Wang, L. Yang, D.H. Jiang, G.Q. Li, T. Hsiang, and W.Y. Zhuang. 2014. Morphological and phylogenetic identification of Botrytis sinoviticola, a novel cryptic species causing gray mold disease of table grapes (Vitis vinifera) in China. Mycologia 106:43-56.

Zoecklein, B.W., T.K. Wolf, N.W. Duncan, J.M. Judge, and M.K. Cook. 1992. Effects of fruit zone leaf removal on yield, fruit composition, and fruit rot incidence of Chardonnay and White Riesling (Vitis vinifera L.) grapes. Am. J. Enol. Vitic.43:139-148.

Zoffoli, J.P., B.A. Latorre, and P. Naranjo. 2008. Hairline, a postharvest cracking disorder in table grapes induced by sulfur dioxide. Postharv. Biol. Technol. 47:90-97.

Zoffoli, J.P., B.A. Latorre, J. Rodríguez, and J.M. Aguilera. 2009. Biological indicators to estimate the prevalence of gray mold and hairline cracks on table grapes cv. Thompson Seedless after cold storage. Postharv. Biol. Technol. 52:126-133. 